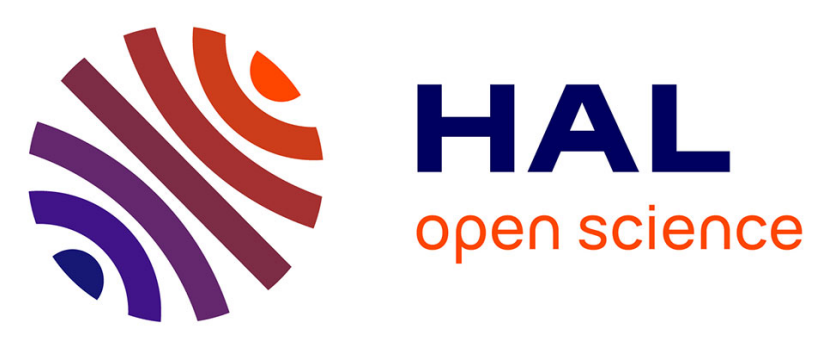

\title{
Quantification of carbon dioxide, methane, nitrous oxide and chloroform emissions over Ireland from atmospheric observations at Mace Head
}

Sébastien Biraud, Philippe Ciais, Michel Ramonet, Peter Simmonds, Victor Kazan, Patrick Monfray, Simon O’Doherty, Gerard Spain, S. Gerrard Jennings

\section{To cite this version:}

Sébastien Biraud, Philippe Ciais, Michel Ramonet, Peter Simmonds, Victor Kazan, et al.. Quantification of carbon dioxide, methane, nitrous oxide and chloroform emissions over Ireland from atmospheric observations at Mace Head. Tellus B - Chemical and Physical Meteorology, 2002, 54 (1), pp.41-60. 10.3402/tellusb.v54i1.16647 . hal-02923908

\section{HAL Id: hal-02923908 \\ https://hal.science/hal-02923908}

Submitted on 29 Oct 2020

HAL is a multi-disciplinary open access archive for the deposit and dissemination of scientific research documents, whether they are published or not. The documents may come from teaching and research institutions in France or abroad, or from public or private research centers.
L'archive ouverte pluridisciplinaire HAL, est destinée au dépôt et à la diffusion de documents scientifiques de niveau recherche, publiés ou non, émanant des établissements d'enseignement et de recherche français ou étrangers, des laboratoires publics ou privés. 


\section{Quantification of carbon dioxide, methane, nitrous oxide and chloroform emissions over Ireland from atmospheric observations at Mace Head}

Sébastien Biraud, Philippe Ciais, Michel Ramonet, Peter Simmonds, Victor Kazan, Patrick Monfray, Simon O'doherty, Gerard Spain \& S. Gerrard Jennings

To cite this article: Sébastien Biraud, Philippe Ciais, Michel Ramonet, Peter Simmonds, Victor Kazan, Patrick Monfray, Simon O'doherty, Gerard Spain \& S. Gerrard Jennings (2002) Quantification of carbon dioxide, methane, nitrous oxide and chloroform emissions over Ireland from atmospheric observations at Mace Head, Tellus B: Chemical and Physical Meteorology, 54:1, 41-60, DOI: 10.3402/tellusb.v54i1.16647

To link to this article: https://doi.org/10.3402/tellusb.v54i1.16647 (c) 2002 The Author(s). Published by Taylor \& 曲 Published online: 15 Dec 2016.
Francis.

Submit your article to this journal $\widetilde{ }$

III Article views: 125

Q View related articles $₫$

Citing articles: 15 View citing articles $\asymp$ 


\title{
Quantification of carbon dioxide, methane, nitrous oxide and chloroform emissions over Ireland from atmospheric observations at Mace Head
}

\author{
By SÉBASTIEN BIRAUD ${ }^{1 *}$, PHILIPPE CIAIS ${ }^{1}$, MICHEL RAMONET ${ }^{1}$, PETER SIMMONDS ${ }^{2}$, \\ VICTOR KAZAN ${ }^{1}$, PATRICK MONFRAY ${ }^{1}$, SIMON O'DOHERTY ${ }^{2}$, GERARD SPAIN ${ }^{3}$ and \\ S. GERRARD JENNINGS ${ }^{3},{ }^{1}$ Laboratoire des Sciences du Climat et de l'Environnement, (UMR \\ CEA/CNRS 1572), C.E. de L'Orme des Merisiers, 91191 Gif-sur-Yvette Cédex, France; ${ }^{2}$ School of \\ Chemistry, University of Bristol, Cantock's Close, Bristol BS8 1TS, United Kingdom; ${ }^{3}$ Department of \\ Experimental Physics, National University of Ireland, Galway, Ireland
}

(Manuscript received 10 July 2000; in final form 10 October 2001)

\begin{abstract}
Flux estimates of $\mathrm{CO}_{2}, \mathrm{CH}_{4}, \mathrm{~N}_{2} \mathrm{O}$ and $\mathrm{CHCl}_{3}$ over Ireland are inferred from continuous atmospheric records of these species. We use radon-222 $\left({ }^{222} \mathrm{Rn}\right)$ as a reference compound to estimate unknown sources of other species. The correlation between each species and ${ }^{222} \mathrm{Rn}$ is calculated for a suite of diurnal events that have been selected in the Mace Head record over the period 1995-1997 to represent air masses exposed to sources over Ireland. We established data selection criteria based on ${ }^{222} \mathrm{Rn}$ and ${ }^{212} \mathrm{~Pb}$ concentrations. We estimated flux densities of $12 \times 10^{3} \mathrm{~kg} \mathrm{CH}_{4} \mathrm{~km}^{-2} \mathrm{yr}^{-1}, 680 \mathrm{~kg} \mathrm{~N}_{2} \mathrm{O} \mathrm{km}{ }^{-2} \mathrm{yr}^{-1}$ and $20 \mathrm{~kg} \mathrm{CHCl}_{3} \mathrm{~km}^{-2} \mathrm{yr}^{-1}$ for $\mathrm{CH}_{4}$, $\mathrm{N}_{2} \mathrm{O}$ and $\mathrm{CHCl}_{3}$, respectively. We also inferred flux densities of $250 \times 10^{3} \mathrm{~kg} \mathrm{C} \mathrm{km}^{-2} \mathrm{yr}^{-1}$ for $\mathrm{CO}_{2}$ during wintertime, and of $760 \times 10^{3} \mathrm{~kg} \mathrm{C} \mathrm{km}^{-2} \mathrm{yr}^{-1}$ for $\mathrm{CO}_{2}$ during summer night-time. Our $\mathrm{CH}_{4}$ inferred flux compare well with the CORINAIR90 and CORNAIR94 inventories for Ireland. The $\mathrm{N}_{2} \mathrm{O}$ emission flux we inferred is close to the inventory value by CORINAIR90, but twice the inventory value by CORINAIR94 and EDGAR 2.0. This discrepancy may have been caused by the use of the revised 1996 IPCC guidelines for national greenhouse gas inventories in 1994, which include a new methodology for $\mathrm{N}_{2} \mathrm{O}$ emissions from agriculture. We carried out the first estimation of $\mathrm{CHCl}_{3}$ emission fluxes over Ireland. This estimation is 4 times larger than the $\mathrm{CHCl}_{3}$ emission fluxes measured close to the Mace Head station over peatlands. Our $\mathrm{CHCl}_{3}$ emission fluxes estimate is consistent with the interpretation of the same data by Ryall (personal communication, 2000), who obtained, using a Lagrangian atmospheric transport model, $\mathrm{CHCl}_{3}$ fluxes of $24 \pm 7 \mathrm{~kg} \mathrm{CHCl} \mathrm{km}^{-2} \mathrm{yr}^{-1}$. Our estimates of $\mathrm{CO}_{2}$ emission fluxes during summer night-time and wintertime are close to those estimated from inventories and to one biogeochemical model of heterotrophic respiration.
\end{abstract}

\section{Introduction}

The major greenhouse gases in the atmosphere are increasing mainly in response to human activities. The main infrared active gases after water

\footnotetext{
* Corresponding author. e-mail: sbiraud@atmos.berkeley.edu
}

vapor are carbon dioxide $\left(\mathrm{CO}_{2}\right)$, methane $\left(\mathrm{CH}_{4}\right.$, and nitrous oxide $\left(\mathrm{N}_{2} \mathrm{O}\right)$. The atmospheric burden of $\mathrm{CO}_{2}$, is still increasing as a result of inputs from fossil fuel combustion and net destruction of forests, primarily in the tropics [Intergovernmental Panel on Climate Change (IPCC), 1994]. Most countries have ratified the United Nations Framework Convention on Climate Change 
(UNFCCC), which aims at 'the stabilization of greenhouse gases in the atmosphere'. The Kyoto protocol, which sets out the first step towards achieving this goal by reducing fossil fuel emissions and the net emissions from some terrestrial ecosystems in developed countries, asks for a quantification of the $\mathrm{CO}_{2}$ fluxes on the continental or regional scale. The European Union (EU) will meet an $8 \%$ reduction of $\mathrm{CO}_{2}, \mathrm{CH}_{4}$ and $\mathrm{N}_{2} \mathrm{O}$ taken together below 1990 levels by 2010. Ireland has indicated that it will contribute to the achievement of the overall EU reduction objective resulting from the Protocol negotiations by means of an indicative national objective of limiting the growth, in the period up to 2010, in its total emissions of $\mathrm{CO}_{2}, \mathrm{CH}_{4}$ and $\mathrm{N}_{2} \mathrm{O}$ together to $13 \%$ above their 1990 levels (Department of the Environment, Ireland).

In addition, there has been a sustained interest in natural emissions of chlorine-containing gases driven by the discovery that man-made chlorofluorocarbons can deplete ozone in the stratosphere (Molina and Rowland, 1974). Chloroform $\left(\mathrm{CHCl}_{3}\right)$ is among the significant carriers of organically bound chlorine into the atmosphere. There is no regional estimate of the $\mathrm{CHCl}_{3}$ sources and the global budget is still not closed, with terrestrial sources and sinks remaining largely not quantified. Apart from emissions due to industrial processes, $\mathrm{CHCl}_{3}$ is produced during anthropogenic activities such as chlorination of drinking and swimming water, pulp and paper bleaching (Aucott et al., 1999). In addition to these anthropogenic sources, $\mathrm{CHCl}_{3}$ has been found to be produced from natural sources such as savanna fires (Rudolph et al., 1995), volcanoes, hydrothermal sources and salt mines (Isidorov et al., 1990). $\mathrm{CHCl}_{3}$ is also naturally produced in soil (Frank and Frank, 1990; Hoekstra et al., 1998) through natural chlorination and bromination of organic material. At the global scale, Keene et al. (1999) have shown that natural sources of $\mathrm{CHCl}_{3}$ dominate its tropospheric cycle. Estimated emissions from anthropogenic sources account for only $10 \%$ of the estimated total from all sources. Although anthropogenic sources of $\mathrm{CHCl}_{3}$ are relatively insignificant at a global level, it should be noted that industrial releases of $\mathrm{CHCl}_{3}$, concentrated at specific point sources, might have severe local or regional impacts on emission flux estimates. It is believed that $\mathrm{CHCl}_{3}$ emission fluxes from soils are strongly correlated with halide ion concentrations (Hoekstra et al., 1998) leading to $\mathrm{CHCl}_{3}$ natural emission fluxes larger in coastal areas. The atmospheric lifetimes have been estimated to be on the order of $14 \mathrm{yr}$, $120 \mathrm{yr}$ and 6 months for $\mathrm{CH}_{4}, \mathrm{~N}_{2} \mathrm{O}$ and $\mathrm{CHCl}_{3}$, respectively (IPCC, 1994; Khalil and Rasmussen, 1999).

In a previous study, using data from Mace Head atmospheric research station (Ireland), we estimated western European (medium range continental events) greenhouse gas emission fluxes using radon-222 $\left({ }^{222} \mathrm{Rn}\right)$ as a reference compound (Biraud et al., 2000; Wilson et al., 1997). In this study we propose to focus on air masses originating from Ireland (regional scale). Firstly, we select data according to their ${ }^{222} \mathrm{Rn}$ and lead-212 $\left({ }^{212} \mathrm{~Pb}\right)$ concentrations, in order to remove oceanic influences. Secondly, we discriminate synoptic events according to their distance of influence. To estimate $\mathrm{CO}_{2}, \mathrm{CH}_{4}, \mathrm{~N}_{2} \mathrm{O}$ and $\mathrm{CHCl}_{3}$ emission fluxes over Ireland, we focus on events whose estimated distance of influence is lower than $300 \mathrm{~km}$. The results are then compared to emission inventories from Core Inventories Air 1990 and 1994 (CORINAIR9O and CORINAIR94) (McInnes, 1995), Emission Database for Global Atmospheric Research (EDGAR 2.0) developed by the National Institute for Public Health (RIVM) (Olivier et al., 1999), and direct $\mathrm{CHCl}_{3}$ flux measurements over Ireland.

\section{The Mace Head record of atmospheric trace gases}

Mace Head atmospheric research station is located in Ireland, on the western coast of Connemara at $53^{\circ} 20^{\prime} \mathrm{N}, 9^{\circ} 54^{\prime} \mathrm{W}, 5 \mathrm{~m}$ above sea level (asl), near the village of Carna (130 inhabitants) in County Galway. The station is situated $90 \mathrm{~m}$ from the shore, and is surrounded with peatlands and wetlands. The closest urban area, Galway (57000 inhabitants) is $88 \mathrm{~km}$ to the east of the station. A study by Bousquet et al. (1996) showed that according to 5-d back trajectories analysis over the period 1992/94, regional air masses (Ireland), formed within a circle of radius $400 \mathrm{~km}$ centered on Mace Head station, comprised around $5 \%$ of the overall $\mathrm{CO}_{2}$ events.

$\mathrm{CH}_{4}, \mathrm{~N}_{2} \mathrm{O}$ and $\mathrm{CHCl}_{3}$ have been measured 
continuously at Mace Head since 1987. A detailed description of the GC analytical system, calibration and estimates of the analytical precision is given by Simmonds et al. (1996). Species $\mathrm{CH}_{4}$, $\mathrm{N}_{2} \mathrm{O}$ and $\mathrm{CHCl}_{3}$ are measured every $40 \mathrm{~min}$ (one injection every $40 \mathrm{~min}$ ). $\mathrm{CO}_{2}$ has been monitored continuously using NDIR technique since July 1992. A description of the measurement protocol and estimated analytical precision is reported in Gaudry et al. (1995) and Ramonet et al. (1998). $\mathrm{CO}_{2}$ concentration is measured every minute then averaged on an hourly basis. ${ }^{222} \mathrm{Rn}$ and ${ }^{212} \mathrm{~Pb}$ have been monitored since mid-1995 in order to identify continental influences. ${ }^{222} \mathrm{Rn}$ is a radioactive noble gas, produced by the radioactive decay of radium-226, which is contained in soils with a concentration ranging between 0.2 and $0.4 \mathrm{pCi} \mathrm{g}^{-1}$ (Nazaroff, 1992). ${ }^{222} \mathrm{Rn}$ is emitted to the atmosphere via diffusion processes in soils and diluted into the atmosphere by turbulent mixing where it stays with a half-life of 3.8 days. The ${ }^{222} \mathrm{Rn}$ emission rate over the continents has been measured by many authors and ranges between 0 atom $\mathrm{cm}^{-2} \mathrm{~s}^{-1}$ for wetlands to few ten of atoms $\mathrm{cm}^{-2} \mathrm{~s}^{-1}$ for soils with high uranium concentrations (Turekian et al., 1997). The main cause of the source flux variations is soils texture, moisture and land cover. However, the mean ${ }^{222} \mathrm{Rn}$ source over large continental areas ranges between 0.5 and 1.3 atoms $\mathrm{cm}^{-2} \mathrm{~s}^{-1}$ (Lambert et al., 1982). Furthermore, ${ }^{222} \mathrm{Rn}$ exhalation from soils turned out to be homogeneous over a restricted area (Dörr and Munnich, 1990). The oceanic source of ${ }^{222} \mathrm{Rn}$, from dissolved ${ }^{226} \mathrm{Ra}$, is 100 to 1000 times lower than the continental source and thus will be neglected in our study (Wilkening and Clements, 1975). The short-lived ${ }^{222} \mathrm{Rn}$ daughters are rapidly absorbed onto submicronic-sized aerosol particles. The lifetime of this active deposit (about $30 \mathrm{~min}$ ) is much lower than the mean lifetime of the aerosol particles in the atmosphere (about 1 week). It can be assumed that under most meteorological conditions and a few hours away from continental sources of ${ }^{222} \mathrm{Rn}$, the short-lived ${ }^{222} \mathrm{Rn}$ daughters are in secular equilibrium with atmospheric ${ }^{222} \mathrm{Rn}$ (Polian et al., 1986). Thus, at Mace Head, ${ }^{222} \mathrm{Rn}$ is measured with the active deposit method (Biraud et al., 2000) assuming no disequilibrium factor. ${ }^{212} \mathrm{~Pb}$ results from the alpha decay series of thorium-232 and is the daughter of the very short-lived ${ }^{220} \mathrm{Rn}(51.5 \mathrm{~s})$. Note that
${ }^{212} \mathrm{~Pb}$ is distinct from ${ }^{222} \mathrm{Rn}$ due to its short radioactive period (half-life of $10.6 \mathrm{~h}$ ) and the fact that it is transported as aerosol in the atmospheric boundary layer (ABL). In practice, the total active deposits of ${ }^{222} \mathrm{Rn}$ and ${ }^{212} \mathrm{~Pb}$ are collected on a filter and identification of alpha disintegration due to ${ }^{222} \mathrm{Rn}$ daughters or ${ }^{212} \mathrm{~Pb}$ can be made according to their different lifetimes (Polian et al., 1986). Overall, the measurements of ${ }^{212} \mathrm{~Pb}$ provide a fingerprint of the regional air masses of recent origin (half a day), while ${ }^{222} \mathrm{Rn}$ acts as a mediumrange continental tracer at synoptic timescales (about 4 days).

\section{Data analysis and data selection for air masses influenced by Ireland}

In a first study by Bousquet et al. (1996), background data selection was performed in order to focus on air masses that were representative of large areas. Marine and continental baseline conditions were thus defined by selecting data according to wind speed and direction as well as the stability of $\mathrm{CO}_{2}$ concentrations. Such selected data are used in inverse modeling, in order to infer surface sources and sinks of $\mathrm{CO}_{2}$ over large regions (Bousquet et al., 1999). In Biraud et al. (2000), we focussed on medium-range continental events originating from the European continent. Data selection according to both meteorological criteria (wind speed and wind direction) and to ${ }^{222} \mathrm{Rn}$ and ${ }^{212} \mathrm{~Pb}$ thresholds allowed us to identify medium range continental events from western Europe, and to use this data set to infer emission fluxes of $\mathrm{CO}_{2}, \mathrm{CH}_{4}, \mathrm{~N}_{2} \mathrm{O}$ and $\mathrm{CFCs}$ over western Europe. In both previous data selections (background and European), we aimed to screen out the influence of Irish sources. However, in this paper we analyze regional sources by selecting regional synoptic events strongly influenced by Irish emissions.

\subsection{Example of an atmospheric event influenced by local sources}

Figure 1 shows a succession of 10 diurnal events occurring during the period 6-15 May 1996. Between 6 May and 10 May, the wind direction changed repeatedly from westerly (daytime, 08:00 to 18:00) to easterly directions (nighttime, 18:00 to $08: 00$ ), possibly reflecting the sea breeze and 


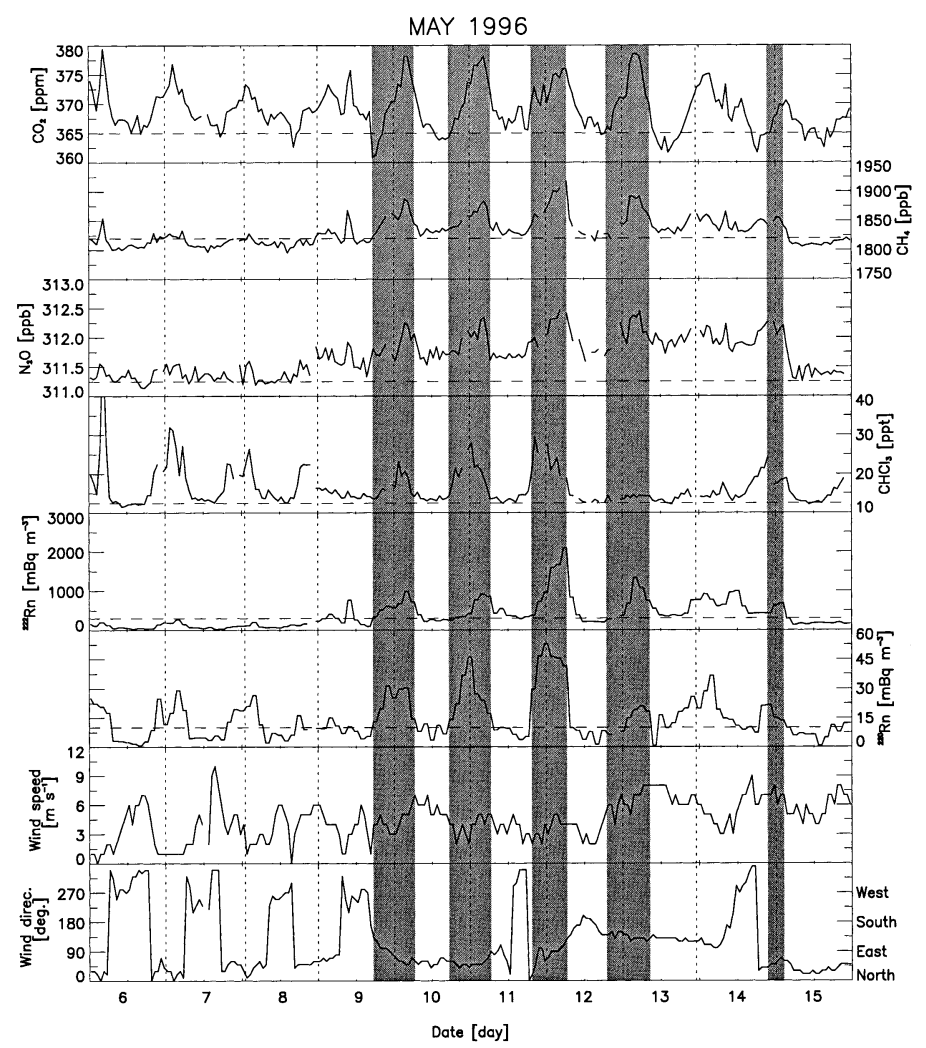

Fig. 1. Example of hourly changes in the concentration of $\mathrm{CO}_{2}, \mathrm{CH}_{4}, \mathrm{~N}_{2} \mathrm{O}, \mathrm{CHCl}_{3},{ }^{222} \mathrm{Rn}$ and ${ }^{212} \mathrm{~Pb}$, together with local wind speed and wind direction $\left(0^{\circ}\right.$ corresponds to north) for a local 'event' between 6 and 15 May 1996 . The horizontal dashed lines in the ${ }^{222} \mathrm{Rn}$ and ${ }^{212} \mathrm{~Pb}$ panels are the thresholds of event selection (data above the threshold are retained). The shaded gray bands denote the 'events' retained to calculate the regional fluxes.

the land breeze, respectively. Elevated concentrations in $\mathrm{CO}_{2}, \mathrm{CHCl}_{3}$ and ${ }^{212} \mathrm{~Pb}$ systematically correlated with winds from the land sector with a fetch estimated to less than $50 \mathrm{~km}$. We also note that ${ }^{222} \mathrm{Rn}$ remains quite low over this period, perhaps due to low local ${ }^{222} \mathrm{Rn}$ emission fluxes by wetlands (see discussion below). From 10 May to 14 May at 10:00, easterly winds prevailed bringing elevated values of $\mathrm{CH}_{4}, \mathrm{~N}_{2} \mathrm{O}$ and ${ }^{222} \mathrm{Rn}$. Wind speeds ranged between 1.5 and $8 \mathrm{~m} \mathrm{~s}^{-1}$, corresponding to fetch events from 150 to $200 \mathrm{~km}$. Diurnal changes in gaseous concentrations occurred, with maximum concentrations in the morning and minimum concentrations in the afternoon. On 12 May at 15:00, the wind speed built up to $8 \mathrm{~m} \mathrm{~s}^{-1}$, advecting remote continental air, and 'regional' species $\mathrm{CHCl}_{3}$ and ${ }^{212} \mathrm{~Pb}$ showed a mid-day maximum of smaller amplitude. On
14 May at 17:00, the wind direction moved to the northeast, advecting air from the ocean accompanied by a decrease in concentration of all species.

\subsection{Selection of events influenced by emissions in Ireland}

We selected the Mace Head continuous measurements to retain events for retrieving emissions over Ireland. For this purpose, we used ${ }^{222} \mathrm{Rn}$ and ${ }^{212} \mathrm{~Pb}$ to indicate continental sources, together with meteorological records to restrict our source estimates to Ireland and avoid including remote European emissions. The data selection criteria were based on the following three points: $(1)^{222} \mathrm{Rn}$ concentrations to be greater than $300 \mathrm{mBq} \mathrm{m}^{-3}$, (2) ${ }^{212} \mathrm{~Pb}$ concentrations to be greater than $10 \mathrm{mBq} \mathrm{m}^{-3}$, and (3) that sources which contrib- 
ute changes in concentration are located in Ireland. We proceeded in two steps to meet these criteria.

The first step was to use ${ }^{222} \mathrm{Rn}$ and ${ }^{212} \mathrm{~Pb} .{ }^{222} \mathrm{Rn}$ reflects both medium range and regional continental influence (half-life 3.8 days), whereas ${ }^{212} \mathrm{~Pb}$ is a tracer of immediate continental contamination (half-life $10.6 \mathrm{~h}$ ). Possible combinations of ${ }^{222} \mathrm{Rn}$ and ${ }^{212} \mathrm{~Pb}$ comprises: (1) low ${ }^{222} \mathrm{Rn}$ and low ${ }^{212} \mathrm{~Pb}$ concentrations, denoting 'background' air masses which have not been over land for several days. Such 'clean marine air' masses were those initially sought at Mace Head for global studies (Bousquet et al., 1999) but are discarded here; (2) high ${ }^{212} \mathrm{~Pb}$ and low ${ }^{222} \mathrm{Rn}$ levels, associated with air masses that have not been over land for several days, but are strongly affected by emission sources located close to the shore (less than $50 \mathrm{~km}$ inland). Such 'local range' events are not taken into account here to minimize the influence of sources closely surrounding the Mace Head station; (3) high ${ }^{222} \mathrm{Rn}$ and low ${ }^{212} \mathrm{~Pb}$ levels, characterizing air that has been transported with low dispersion from distant land sources without being affected by local emissions. Such 'medium range' continental events were analyzed by Biraud et al. (2000) for western European sources and were not of interest here; (4) high ${ }^{222} \mathrm{Rn}$ and high ${ }^{212} \mathrm{~Pb}$ concentrations corresponding to 'stagnant' air exposed to Irish emissions. In the present study, we focused only on that latter type of air masses. We selected data for which ${ }^{222} \mathrm{Rn}$ and ${ }^{212} \mathrm{~Pb}$ concentrations were both greater than thresholds of 300 and $10 \mathrm{mBq} \mathrm{m}^{-3}$, respectively. These thresholds were defined by the average of ${ }^{222} \mathrm{Rn}$ and ${ }^{212} \mathrm{~Pb}$ over the full time series. We defined an 'event' as a group of at least five consecutive data points in the time series that verified these two criteria. According to these criteria, we selected 175, 173, 189 and 193 events over the period 1995-97 for species $\mathrm{CO}_{2}, \mathrm{CH}_{4}, \mathrm{~N}_{2} \mathrm{O}$ and $\mathrm{CHCl}_{3}$, respectively (the numbers for each species differ only because of gaps in their respective records). The average wind speed and the mean duration associated with such selected regional events are of the order of $5.1 \mathrm{~m} \mathrm{~s}^{-1}$ and $17 \mathrm{~h}$, leading to an average distance of influence of around $300 \mathrm{~km}$. This data selection alone can include some medium range continental events that were formerly selected to estimate western European fluxes (Biraud et al., 2000), where ${ }^{222} \mathrm{Rn}$ and ${ }^{212} \mathrm{~Pb}$ data selection thresholds were set up to $1000 \mathrm{mBq} \mathrm{m}^{-3}$ (lower limit) and $40 \mathrm{mBq} \mathrm{m}^{-3}$ (upper limit), respectively.

The second step was to use low wind speed to further select events strongly influenced by emissions in Ireland. We define the fetch of a synoptic event as the product of the average wind speed recorded during the synoptic event by the time duration of the considered synoptic event. Events are retained if their fetch ranges between 50 and $300 \mathrm{~km}$, the maximum distance which roughly encompasses the North-South $(480 \mathrm{~km})$ or East-West $(300 \mathrm{~km})$ extension of Ireland. According to this criterion, we selected 121, 121, 130 and 134 events for species $\mathrm{CO}_{2}, \mathrm{CH}_{4}, \mathrm{~N}_{2} \mathrm{O}$ and $\mathrm{CHCl}_{3}$, respectively. The average wind speed associated with these Irish events is $4.7 \mathrm{~m} \mathrm{~s}^{-1}$ over the $10.5 \mathrm{~h}$ period corresponding to the mean duration of those events. It suggests that selected air masses traveled on average a distance of about $180 \mathrm{~km}$ before reaching Mace Head. Figure 2 displays the number of selected events according to the data selection and to the fetch. Alternatively, using isobaric back-trajectories (Ramonet et al., 1996) based on ECMWF wind fields (European Center for Meteorological World Forecast (ECMWF), 1994) to estimate the distance of influence with $12 \mathrm{~h}$ duration for each individual event, we estimated a fetch of about $300 \mathrm{~km}$. This latter value is $50 \%$ larger than that calculated from in-situ wind speed measurements at Mace Head. Possibly, in-situ measured wind speed at Mace Head ( $23 \mathrm{~m}$ above ground level) is more influenced by friction than the average wind speed between 0 and $400 \mathrm{~m}$ used in our back-trajectory model.

Finally, using jointly ${ }^{222} \mathrm{Rn}$ and ${ }^{212} \mathrm{~Pb}$ thresholds, in situ wind speed data (fetch) and a species${ }^{222} \mathrm{Rn}$ correlation coefficient greater than 0.25 , we identified 97, 99, 110 and 104 regional events for $\mathrm{CO}_{2}, \mathrm{CH}_{4}, \mathrm{~N}_{2} \mathrm{O}$, and $\mathrm{CHCl}_{3}$, respectively. The different number of selected events for each species in mainly due to instrumental malfunction. In a previous study (Biraud et al., 2000), we had retained 40 medium-range continental events from Western Europe. There are only 10 events (i.e. $10 \%$ of the total) classified both from Ireland and Europe, which suggests that our present 3-point criterion efficiently separates regional (western European) and local (Irish) events. Interestingly, more than $80 \%$ of the selected local events occur over night-time when air is more stratified, starting 

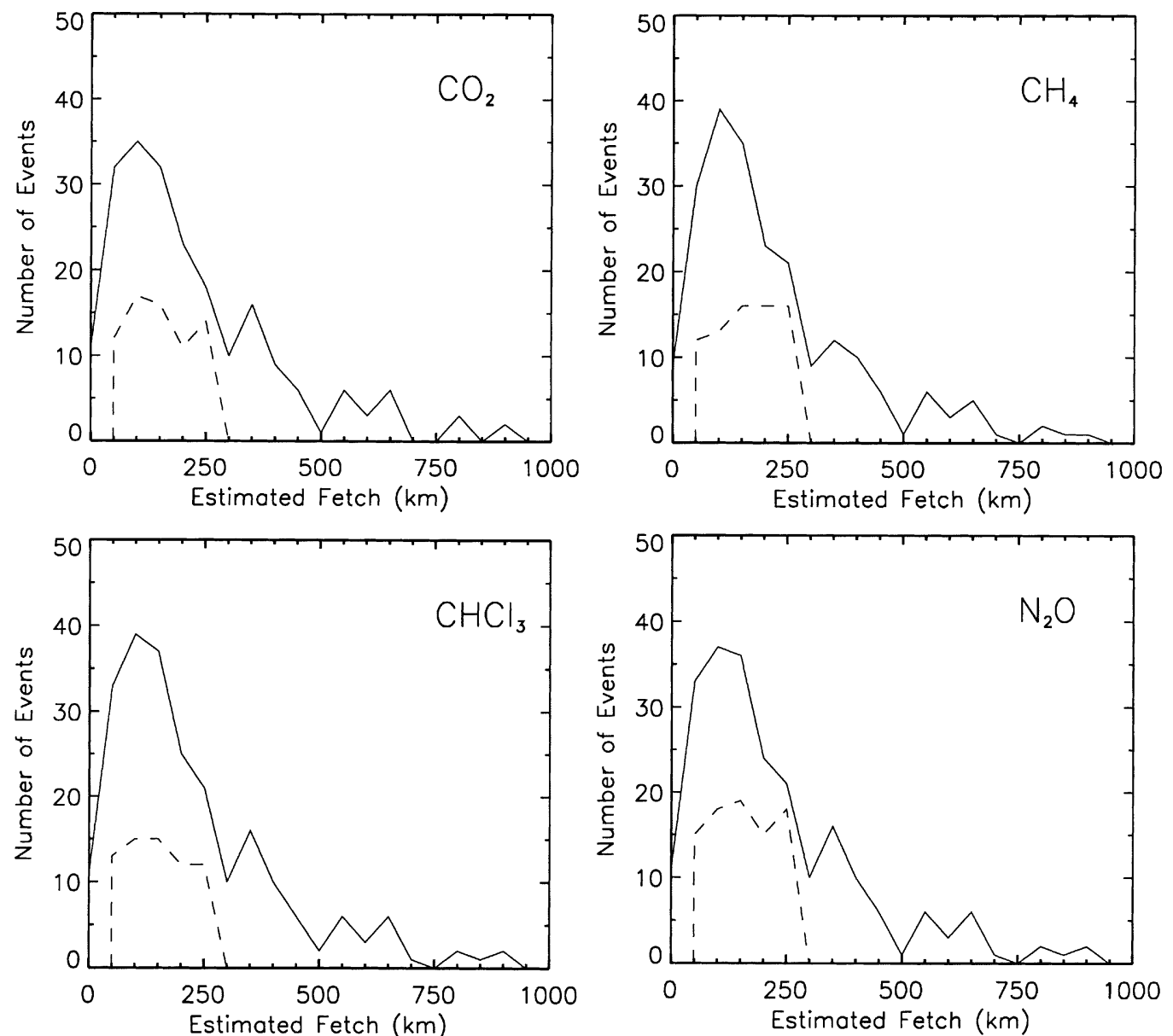

Fig. 2. Number of selected events according to the data selection and to the distance of influence for (a) $\mathrm{CO}_{2}$, (b) $\mathrm{CH}_{4}$, (c) $\mathrm{N}_{2} \mathrm{O}$ and (d) $\mathrm{CHCl}_{3}$. The solid line shows the number of synoptic events selected using only a threshold value for ${ }^{212} \mathrm{~Pb}$ of $10 \mathrm{mBq} \mathrm{m}^{-3}$. The dotted line represents the number of selected events according to the Irish data selection (see text).

at 19:00 and ending at 10:00 in the morning (see Figs. 1 and 3). Over the period 1995/97, the number of selected events represent $5 \%$ of the overall data, which corresponds to the percentage of air masses attributed to a local origin in Bousquet et al. (1996), using back trajectories.

In Fig. 4 we present the time series of $\mathrm{CO}_{2}$, $\mathrm{CH}_{4}, \mathrm{~N}_{2} \mathrm{O}, \mathrm{CHCl}_{3},{ }^{222} \mathrm{Rn}$ and ${ }^{212} \mathrm{~Pb}$ from January 1997 to March 1997. Positive concentration anomalies on a synoptic timescale are observed for all species. Baseline data selected according to Bousquet et al. (1996) correspond to species concentrations in the clean air sector (blue), whereas data selected according to Biraud et al. (2000) (red) and this study (green) correspond to regional and local synoptic events, respectively.

\subsection{Diurnal changes in trace gases}

Diurnal changes in the concentrations of the studied species are observed at Mace Head and deserve some attention. Diurnal concentration changes result from variations of nearby sources and from local changes in atmospheric mixing. During daylight hours in the summertime solar heating generally causes the atmospheric bound- 

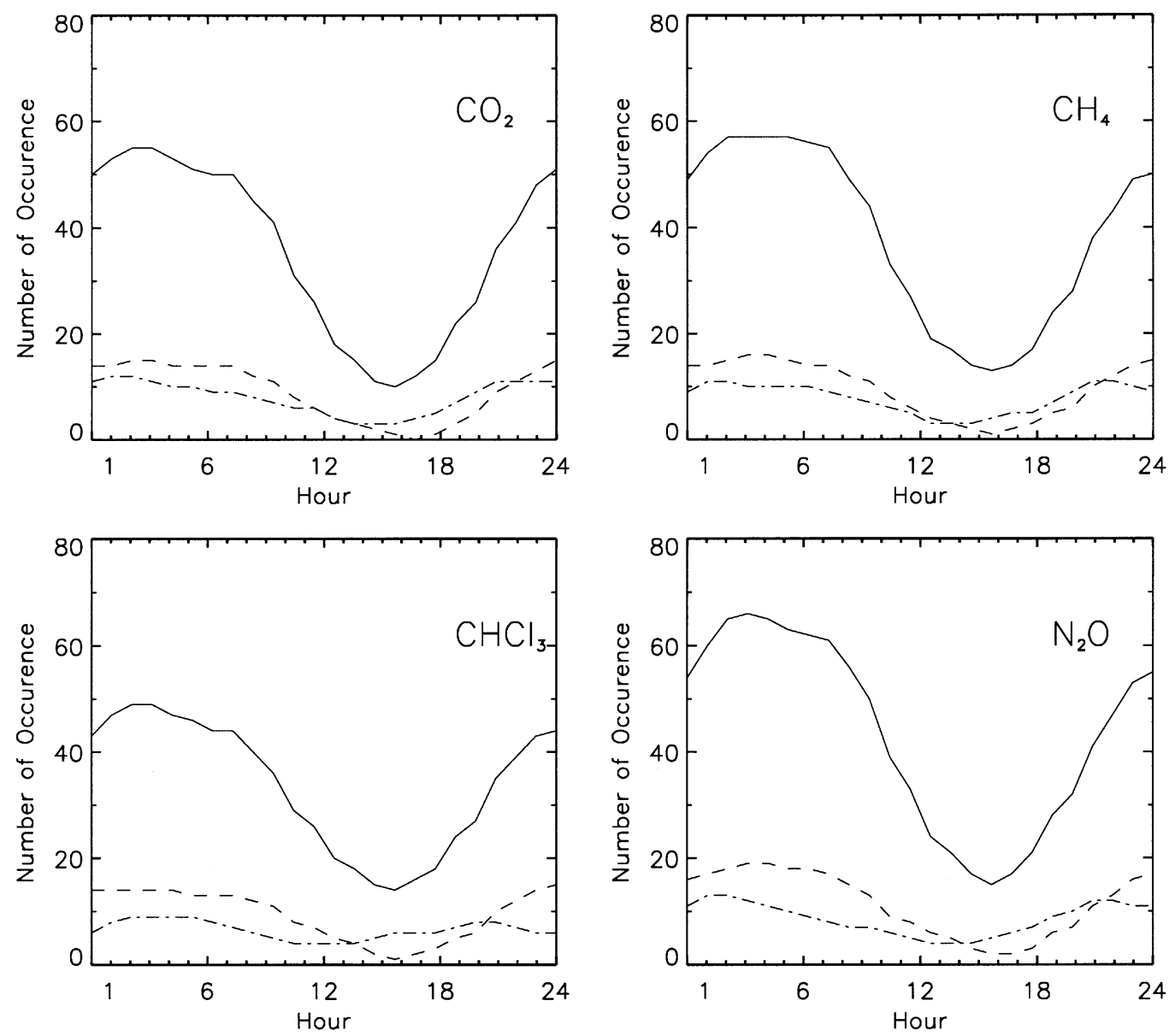

Fig. 3. Frequency distribution of selected hours for the Irish data set for (a) $\mathrm{CO}_{2}$, (b) $\mathrm{CH}_{4}$, (c) $\mathrm{N}_{2} \mathrm{O}$ and (d) $\mathrm{CHCl}_{3}$. Solid lines, dashed lines and dash dotted lines correspond to all, wintertime and summertime selected synoptic events, respectively.

ary layer $(\mathrm{ABL})$ to become unstable. This causes convection and dilution of stable species concentrations. At night, when the surface is cooling, the ABL becomes shallower and species are concentrated near the surface. In addition, shifts in wind direction associated with land-sea breezes at Mace Head may also contribute to the diurnal changes of trace gases (Fig. 1).

Diurnal changes in species concentrations at Mace Head are apparent when calculating the cross-covariance function of each species with ${ }^{222} \mathrm{Rn}$ in the time domain, following the method described in Prather (1988). The cross-covariance of species $x$ and $y$ at the lag time of $L$ is
$C_{x y}(L)=\frac{\sum_{k=0}^{N-L-1} x(k) y(k+L) \delta_{x}(k) \delta_{y}(k+L)}{\sum_{k=0}^{N-L-1} \delta_{x}(k) \delta_{y}(k+L)}$

$d_{x}(k)= \begin{cases}1 & \text { if datum for species } x \text { at time } k \\ 0 & \text { otherwise }\end{cases}$

where $x(k)$ is the time series of the residuals of species $x, y$ is the time series of ${ }^{222} \mathrm{Rn}$, and $N$ is the number of data of the time series $x$ and $y$. Note that the mean value of the time series $x$ and $y$ is zero. To define the residuals, we fit all the data with a curve containing a second-order poly-

Tellus 54B (2002), 1 

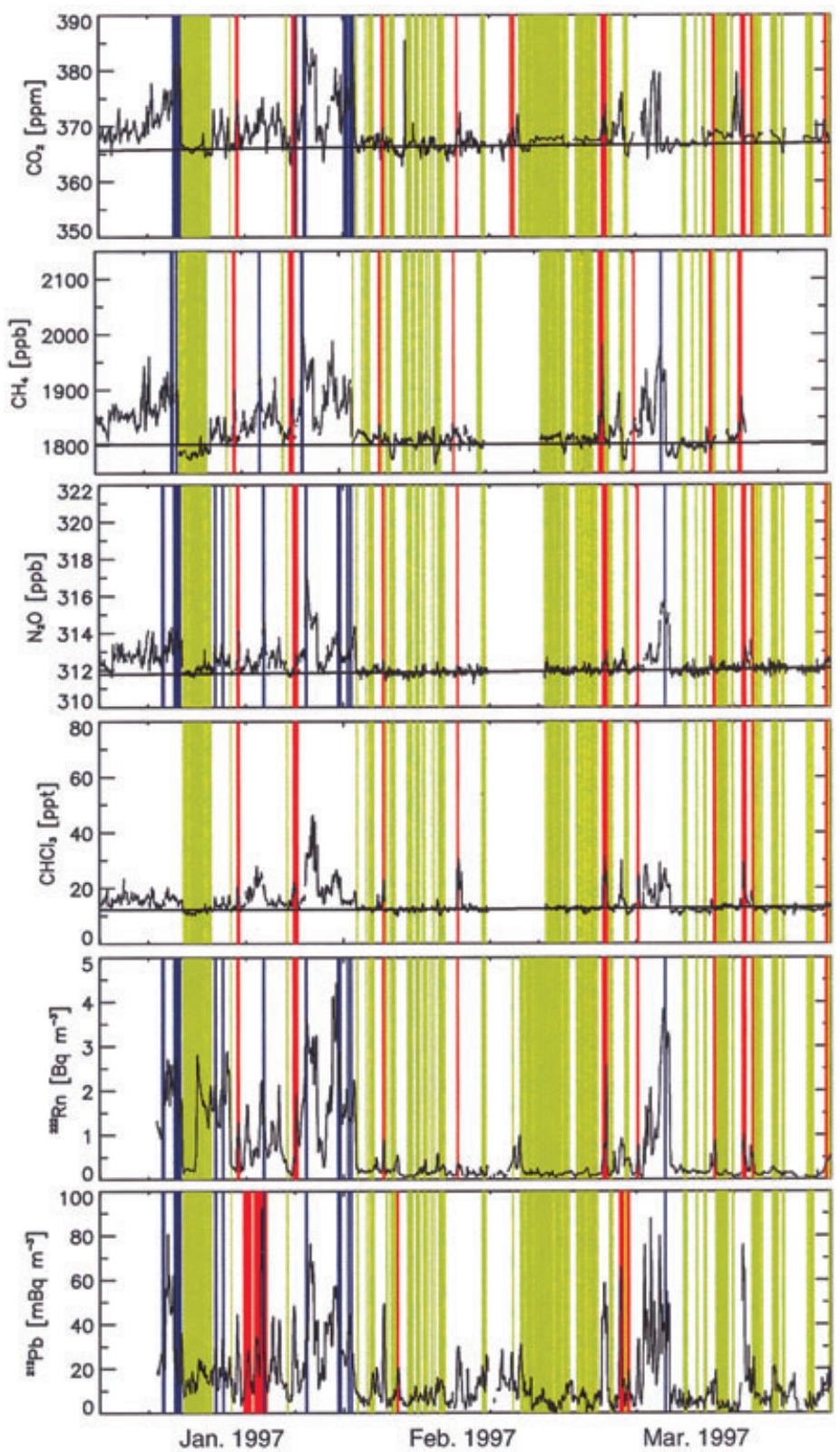

Fig. 4. Atmospheric record of (a) $\mathrm{CO}_{2}$, (b) $\mathrm{CH}_{4}$, (c) $\mathrm{N}_{2} \mathrm{O}$ and (d) $\mathrm{CHCl}_{3}$ together with (e) ${ }^{222} \mathrm{Rn}$ and (f) ${ }^{212} \mathrm{~Pb}$ at Mace Head between January 1997 and March 1997. The solid line defines the marine baseline concentration. Time periods that are retained according to (1) the continental data selection by Bousquet et al. (1996) (blue), (2) the Western Europe events data selection by Biraud et al. (2000) (red), (3) the regional Irish events data selection of this study (green). 
nomial term and four harmonics (Thoning et al., 1994). Deviations of individual measurements from this fit are then filtered in the time domain using a low-pass filter of full width at half maximum of approximately 40 days and added to the initially fitted function, to produce a smoothed time series. The time series of the residuals is obtained by subtracting this smooth time series from the initial time series. To remove the diurnal cycle from the time series of the residuals of species $x$, we computed an hourly averaged value of the time series of the residuals for each month (24 values per month). These hourly values were subtracted from the time series of the residuals for each month. The cross-covariance was calculated for the time series of the residuals (solid line) and for the time series of the residuals after subtracting the mean diurnal cycle. We also calculated the cross-covariance function of each species with ${ }^{222} \mathrm{Rn}$ for all data and for the selected events from Ireland. When focussing on all the data, any species cross-correlated with ${ }^{222} \mathrm{Rn}$, and a lag time up to approximately 2 days (Fig. 5), had collocated sources at 2 days from the station, which identifies western Europe as a major source of concentration changes at Mace Head. The crosscorrelation of $\mathrm{CO}_{2}, \mathrm{CH}_{4}, \mathrm{~N}_{2} \mathrm{O}$ and ${ }^{222} \mathrm{Rn}$ disappeared for lag times larger than about $12 \mathrm{~h}$ (Fig. 5) for the selected events from Ireland. Moreover, the same correlation of $12 \mathrm{~h}$ width is found with a lag of a day. This corresponds to the fact that correlation occurs mainly during successive nights. This approach independently confirms that our data selection effectively removes remote sources influencing the station beyond a $12 \mathrm{~h}$ lag time.

\section{Results and discussion}

\subsection{Estimation of fluxes}

Firstly, we used the linear regression between any species $x$ and ${ }^{212} \mathrm{~Pb}$ to estimate the emission flux of species $x$ as described in Biraud et al. (2000). ${ }^{212} \mathrm{~Pb}$ seemed to be the ideal tracer to estimate local emissions because of its half-life of $10.6 \mathrm{~h}$. However, this method assumes that the flux of ${ }^{212} \mathrm{~Pb}$ over the regions considered is known. Unfortunately, only few measurements of ${ }^{212} \mathrm{~Pb}$ emission flux around the world exist (Schery et al., 1989; Whittlestone et al., 1996). These measurements of ${ }^{212} \mathrm{~Pb}$ flux have shown that ${ }^{222} \mathrm{Rn}$ and
${ }^{212} \mathrm{~Pb}$ are positively correlated reflecting common physical factors affecting transport of both tracers such as diffusivity and soil moisture. Emission fluxes of ${ }^{212} \mathrm{~Pb}$ from soils can vary in the range $(0.7-1.40) \times 10^{-2}$ atom $\mathrm{cm}^{-2} \mathrm{~s}^{-1}$ (Schery, 1986). However, only a variable fraction of ${ }^{212} \mathrm{~Pb}$ reaches the free ABL because it is exhalated near the soil surface and some of it is subsequently deposited on the surface. ${ }^{212} \mathrm{~Pb}$ is the daughter of the very short-lived ${ }^{220} \mathrm{Rn}$. Due to its short lifetime, ${ }^{220} \mathrm{Rn}$ is exhalating from soil depths of only a few centimetres whereas the ${ }^{222} \mathrm{Rn}$ saturation depth is of the order of two metres. Thus, ${ }^{220} \mathrm{Rn}$ exhalation from soil is much more affected by meteorological changes than ${ }^{222} \mathrm{Rn}$. A very wet layer at the surface can drastically reduce the ${ }^{212} \mathrm{~Pb}$ emission flux without affecting the ${ }^{222} \mathrm{Rn}$ emission flux too much. On the other hand, prolonged rain leading to a rise in the water table can reduce the ${ }^{222} \mathrm{Rn}$ flux without affecting ${ }^{212} \mathrm{~Pb}$. We believe that because of this variability, ${ }^{212} \mathrm{~Pb}$ can be used qualitatively to distinguish local air masses from long-range continental air masses, but not quantitatively to estimate emission fluxes.

Secondly, we used the regression between any species $x$ and ${ }^{222} \mathrm{Rn}$ to infer the flux of $x$ using the classical equation (Schmidt et al., 2001)

$\overline{j_{x}}=\overline{j_{222}} \frac{\Delta C_{x}}{\Delta C_{222}} \times\left(1-\frac{\lambda_{222} \times C_{222}}{\frac{\Delta C_{222}}{\Delta t}}\right)$

where $\bar{j}_{x}$ is the average emission of tracer $x$ over Ireland, $\overline{j_{222}}$ is the flux of ${ }^{222} \mathrm{Rn}$ over Ireland, assumed to be constant and uniform, $\Delta t$ the time duration of the considered synoptic events and $\lambda_{222}$ is the ${ }^{222} \mathrm{Rn}$ radioactive constant value of 0.182 day $^{-1}$. This method assumes that the ${ }^{222} \mathrm{Rn}$ flux is quasi-uniform and well determined. Eckhardt (1990) established a ${ }^{222} \mathrm{Rn}$ emission flux map over Europe, according to soil texture. He estimated a mean ${ }^{222} \mathrm{Rn}$ flux over Europe of 0.8 atom $\mathrm{cm}^{-2} \mathrm{~s}^{-1}$, the value chosen in Biraud et al. (2000) to infer the western European flux of various pollutants. The estimation of the mean ${ }^{222} \mathrm{Rn}$ flux over Ireland is more uncertain. Very few ${ }^{222} \mathrm{Rn}$ direct flux measurements have been made. They include one in Ardara, Donegal and another one in the suburb of Dublin (Eckhardt, 1990). These measurements suggest a mean ${ }^{222} \mathrm{Rn}$ flux over Ireland of the order of 

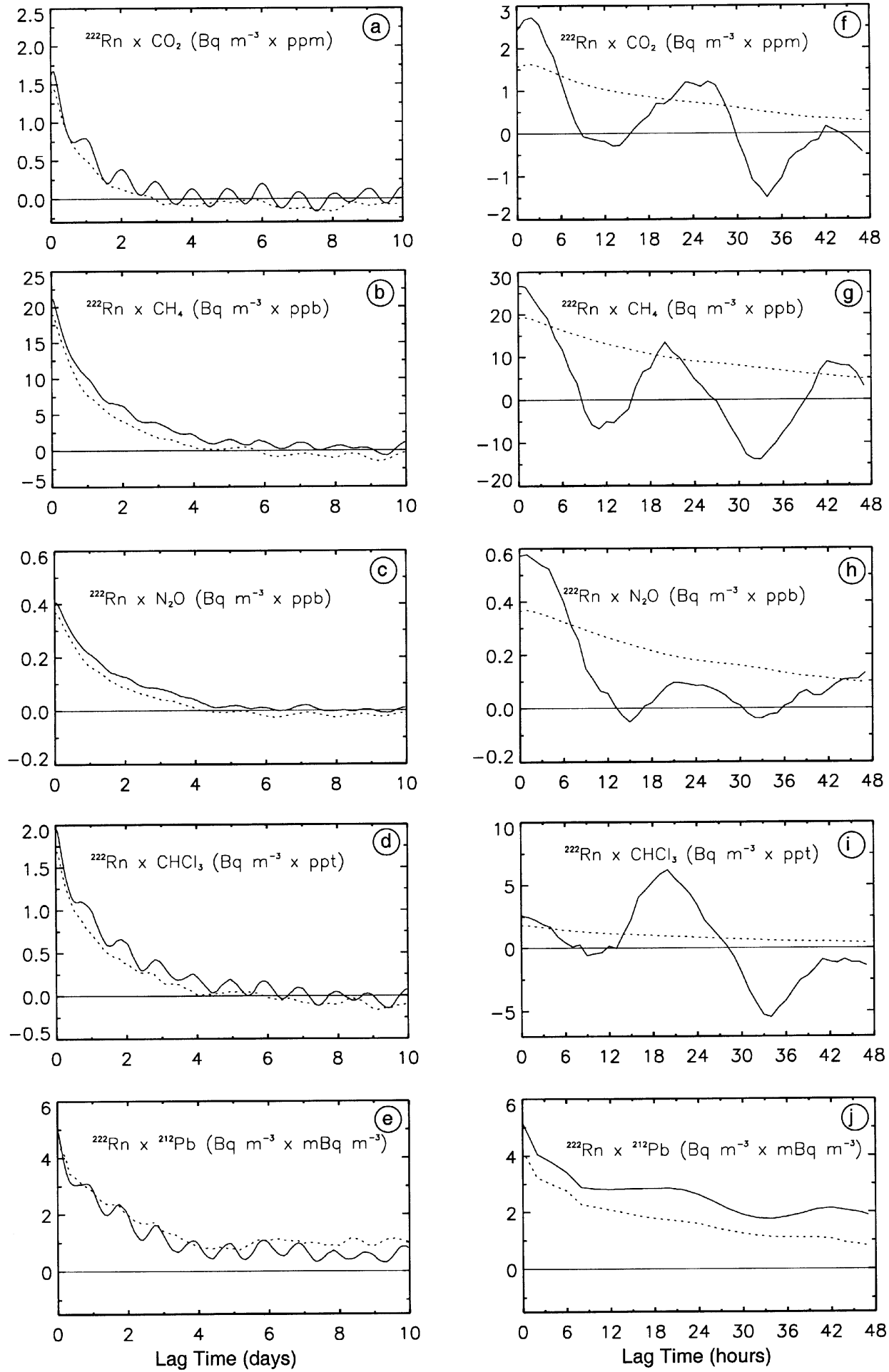

Fig. 5. Cross-covariance of each species with ${ }^{222} \mathrm{Rn}$ plotted against lag time [see eq. (1)]. Seasonal cycle and long term trend were removed from the data using a curve-fitting containing a second-order polynomial term and four harmonics (see text). The dotted lines show data for which the diurnal cycle were also removed. (a)-(e) and (f)-(j), respectively, show cross-correlation calculated using all data and regional Irish selected events, over the period $1995 / 97$. 
0.6 atom $\mathrm{cm}^{-2} \mathrm{~s}^{-1}$. We adopted this estimate to determine the fluxes over Ireland. Note that the ${ }^{222} \mathrm{Rn}$ flux determined for Ireland is $25 \%$ lower than the mean flux over Europe, which may reflect the effect of elevated soil moisture on the ${ }^{222} \mathrm{Rn}$ flux (Whittlestone et al., 1998). For example, the ${ }^{222} \mathrm{Rn}$ fluxes measured at Fraserdale, Ontario by Kuhlmann et al. (1998) in a wetland area did not exceed 0.3 atom $\mathrm{cm}^{-2} \mathrm{~s}^{-1}$. Peat bogs in Ireland represent cover $17 \%$ of the land cover (Table 3) and more than $80 \%$ in the Connemara area where the Mace Head station is located, which could cause the ${ }^{222} \mathrm{Rn}$ flux to be lower than the value we chose. However, as mentioned above, the contribution from local sources (Connemara) close to the station is minimized by the data selection. The uncertainty of the ${ }^{222} \mathrm{Rn}$ exhalation rate is estimated to be on the order of $20 \%$ (Eckhardt, 1990). Adding measurement errors on ${ }^{222} \mathrm{Rn}$ concentrations implies an overall uncertainty of the inferred fluxes on the order of $30 \%$ (Biraud et al., 2000).

We regressed any species with ${ }^{222} \mathrm{Rn}$ for each event selected in the local dataset using a leastsquares polynomial fit method. Starting from individual linear regression slopes associated with a temporal correlation between any species and ${ }^{222} \mathrm{Rn}$ greater than 0.25 , we then inferred an average emission flux for each species every season (December to February, March to May, June to August, and September to November) over the period January 1995 to December 1997. We report the average slope $(S)$ as well as its standard deviation (std) in Table 1 and the resulting fluxes associated in Table 2. Alternatively we calculated the average slope between any species and ${ }^{222} \mathrm{Rn}$ during the full period 1995-97. Both methods give similar results, and we chose to use only the first method to calculate emission fluxes for individual species. One important goal of this study is to compare our inferred emissions with inventories. Like other countries of the European Union, Ireland compiled national emission inventories for trace gases on the basis of statistical data for the years 1990 and 1994. Emission inventories are summarized in CORINAIR90 and CORINAIR94 (McInnes, 1995) and in the EDGAR 2.0 database (Olivier et al., 1999). $\mathrm{CHCl}_{3}$ (Dimmer et al., 2000) and $\mathrm{CO}_{2}$ fluxes show strong diurnal patterns, whereas $\mathrm{CH}_{4}$ (Simpson et al., 1999) and $\mathrm{N}_{2} \mathrm{O}$ (Elser et al., 2000) fluxes show small diurnal patterns. We thus took into account diurnal variations in inventoried emissions for $\mathrm{CO}_{2}$ and $\mathrm{CHCl}_{3}$ but not for $\mathrm{CH}_{4}$ and $\mathrm{N}_{2} \mathrm{O}$.

\subsection{Methane flux estimates}

The $\mathrm{CH}_{4}{ }^{-222} \mathrm{Rn}$ average slope over the period $1995-97$ is on the order of $54 \mathrm{ppb} / \mathrm{Bq} \mathrm{m}^{-3}$ (Table 1). The value of this slope is considerably larger than the one established by Biraud et al. (2000) for Western Europe (13 ppb/Bq m${ }^{-3}$ ). The corresponding inferred $\mathrm{CH}_{4}$ emission flux over Ireland is of $12 \times 10^{3} \mathrm{~kg} \mathrm{CH}_{4} \mathrm{~km}^{-2} \mathrm{yr}^{-1}$.

This range closely agrees with the CORINAIR inventory for Ireland, which reported a $\mathrm{CH}_{4}$ emission flux of $11.5 \times 10^{3}$ and $12 \times 10^{3} \mathrm{~kg} \mathrm{CH}_{4}$ $\mathrm{km}^{-2} \mathrm{yr}^{-1}$ for years 1990 and 1994, respectively. According to the CORINAIR inventories, emissions of $\mathrm{CH}_{4}$ remained relatively stable over the period 1990-1994. The EDGAR 2.0 database estimated a $\mathrm{CH}_{4}$ emission flux over Ireland of $9 \times 10^{3} \mathrm{~kg} \mathrm{CH}_{4} \mathrm{~km}^{-2} \mathrm{yr}^{-1}$ for year 1990. The major difference between these two estimates is due to $\mathrm{CH}_{4}$ emissions from enteric fermentation. CORINAIR90 estimated $7.8 \times 10^{3} \mathrm{~kg}$ $\mathrm{CH}_{4} \mathrm{~km}^{-2} \mathrm{yr}^{-1}$ from enteric fermentation,

Table 1. Summary of the average linear regression slope $(S)$ and of the standard deviation (std) calculated for the period January 1995 through December 1997 between species $\mathrm{CH}_{4}, \mathrm{~N}_{2} \mathrm{O}, \mathrm{CHCl}_{3}, \mathrm{CO}_{2}$, and ${ }^{222} \mathrm{Rn}$

\begin{tabular}{|c|c|c|c|c|c|c|c|c|c|}
\hline & \multirow{2}{*}{$\begin{array}{c}\text { Average } 1995 / 97 \\
S\end{array}$} & \multicolumn{2}{|c|}{ DJF } & \multicolumn{2}{|c|}{ MAM } & \multicolumn{2}{|c|}{ JJA } & \multicolumn{2}{|c|}{ SON } \\
\hline & & $S$ & std & $S$ & std & $S$ & $s t d$ & $S$ & $s t d$ \\
\hline $\mathrm{CH}_{4}$ & 54 & 62 & 6 & 54 & 1.6 & 56 & 3.7 & 43 & 4 \\
\hline $\mathrm{N}_{2} \mathrm{O}$ & 1.2 & 1.4 & 0.2 & 1.8 & 0.1 & 0.9 & 0.1 & 0.7 & 0.1 \\
\hline $\mathrm{CHCl}_{3}$ & 13 & 12 & 0.7 & 13 & 0.9 & 12 & 1.7 & 15 & 3.0 \\
\hline $\mathrm{CO}_{2}$ & 3.2 & 1.5 & 0.2 & 4.3 & 0.5 & 4.6 & 0.5 & 2.6 & 0.3 \\
\hline
\end{tabular}

Units are given in $\mathrm{ppb} / \mathrm{Bq} \mathrm{m}{ }^{-3}$ for $\mathrm{CH}_{4}$ and $\mathrm{N}_{2} \mathrm{O}$, in $\mathrm{ppt} / \mathrm{Bq} \mathrm{m}^{-3}$ for $\mathrm{CHCl}_{3}$, and in $\mathrm{ppm} / \mathrm{Bq} \mathrm{m}^{-3}$ for $\mathrm{CO}_{2}$.

Tellus 54B (2002), 1 
Table 2. Comparison between the estimated fluxes over Ireland, emission flux inventories over Ireland and western European fluxes inferred from Mace Head

\begin{tabular}{lccc}
\hline & $\begin{array}{c}\text { Fluxes over Ireland from } \\
\text { Mace Head atmospheric } \\
\text { observations }\end{array}$ & $\begin{array}{c}\text { Flux inventories } \\
\text { over Ireland }\end{array}$ & $\begin{array}{c}\text { Western European fluxes from } \\
\text { Mace Head atmospheric } \\
\text { observations }\end{array}$ \\
\hline $\mathrm{CH}_{4}$ & 12 & $12^{1}$ & $3.5-4.8$ \\
$\mathrm{~N}_{2} \mathrm{O}$ & 680 & $430^{1}$ & $330-475$ \\
$\mathrm{CHCl}_{3}$ & 20 & $4.5-145^{2}$ & $-50-540$ \\
$\mathrm{CO}_{2}$ winter & 250 & $540^{3}$ & $360-540$ \\
$\mathrm{CO}_{2}$ (summer night-time) & 760 & $795^{4}$ & - \\
\hline
\end{tabular}

${ }^{1}$ Estimated fluxes by CORINAIR94 over Ireland.

${ }^{2}$ Direct flux measurements using flux chambers (Dimmer et al., 2000).

${ }^{3}$ Sum of biospheric release plus fossil fuel emissions from December to February (see text).

${ }^{4} \mathrm{Sum}$ of biospheric release plus fossil fuel emissions from June to August (see text).

Fluxes are expressed in $10^{3} \mathrm{~kg} \mathrm{CH}_{4} \mathrm{~km}^{-2} \mathrm{yr}^{-1}$ for $\mathrm{CH}_{4}$ and in $\mathrm{kg} \mathrm{N}_{2} \mathrm{O} \mathrm{km}^{-2} \mathrm{yr}^{-1}$ for $\mathrm{N}_{2} \mathrm{O}$, in $\mathrm{kg} \mathrm{CHCl}_{3} \mathrm{~km}^{-2} \mathrm{yr}^{-1}$ for $\mathrm{CHCl}_{3}$, and in $10^{3} \mathrm{~kg} \mathrm{C} \mathrm{km}^{-2} \mathrm{yr}^{-1}$ for $\mathrm{CO}_{2}$.

Table 3. Land cover classification over Ireland according to CORINE

\begin{tabular}{lcr}
\hline Land cover type & Surface $\left(\mathrm{km}^{2}\right)$ & $\%$ \\
\hline Pastures & 47875 & 56.5 \\
Peat bogs & 14140 & 16.7 \\
Land principally occupied & & \\
$\quad$ by agriculture & 10280 & 12.1 \\
Natural grassland & 4090 & 4.8 \\
Coniferous forest & 2965 & 3.5 \\
Water bodies & 1815 & 2.1 \\
Others & 3590 & 4.3 \\
\hline
\end{tabular}

while EDGAR 2.0 estimated $6.1 \times 10^{3} \mathrm{~kg} \mathrm{CH}_{4}$ $\mathrm{km}^{-2} \mathrm{yr}^{-1}$ for Ireland in 1990. The fairly large difference is related to differences in the calculation methods and different emission factors. In Ireland, according to the CORINAIR inventory, the major $\mathrm{CH}_{4}$ sources are in order of importance, enteric fermentation $(65 \%)$, waste treatment $(16 \%)$, manure management $(7 \%)$, natural wetlands $(4 \%)$, managed deciduous and coniferous forest $(3 \%)$ and gas distribution network (2\%). Levin et al. (1999), using an approach similar to ours, but aided by methane isotopes, showed that, for southwestern Germany, CORINAIR90 overestimated methane emissions by approximately $50 \%$. This discrepancy was attributed to an overestimation of the emission of $\mathrm{CH}_{4}$ from waste treatment. In Germany, waste treatment represents about half of the total source of methane. An overestimation of this type of emission would then strongly influence the total value of the emissions inventory.
As waste treatment represents only $16 \%$ of the total $\mathrm{CH}_{4}$ emissions over Ireland, any overestimate in waste associated methane emissions by CORINAIR, probably would have less impact on the total inferred emissions of $\mathrm{CH}_{4}$.

Figure 6c displays the $\mathrm{CH}_{4}$ average flux calculated every 3 months (December to February, March to May, June to August and September to November) over the period 1995/97. Firstly, one can notice that the $\mathrm{CH}_{4}$ emission fluxes are seasonal, with a springtime maximum and a fall minimum. We estimate a $\mathrm{CH}_{4}$ springtime flux $50 \%$ larger than the $\mathrm{CH}_{4}$ fall flux. According to CORINAIR90 and CORINAIR94 inventories, the main contribution to $\mathrm{CH}_{4}$ emission flux is due to enteric fermentation $(65 \%$ of the total), which is not seasonal. Hauglustaine et al. (1998) used a global three-dimensional chemical transport model to calculate the global distribution of $\mathrm{OH}$ radicals, which provide the main sink for $\mathrm{CH}_{4}$ destruction in the atmosphere. In the Mace Head latitude band, the $\mathrm{CH}_{4}$ sink due to $\mathrm{OH}$ radicals varies of the order of $50 \%$ between summertime and wintertime. This $\mathrm{CH}_{4}$ sink alone could explain the seasonal variation observed. The relatively short distance between Irish sources and the station may, however, lower the impact of photochemical destruction of $\mathrm{CH}_{4}$ by $\mathrm{OH}$ radicals in the $\mathrm{CH}_{4}$ observed record. In addition, there is a striking correlation between the inferred $\mathrm{CH}_{4}$ flux and precipitation in Ireland (Fig. 6c). This suggests that emissions from wetlands can also significantly contribute to the observed flux seasonality. 

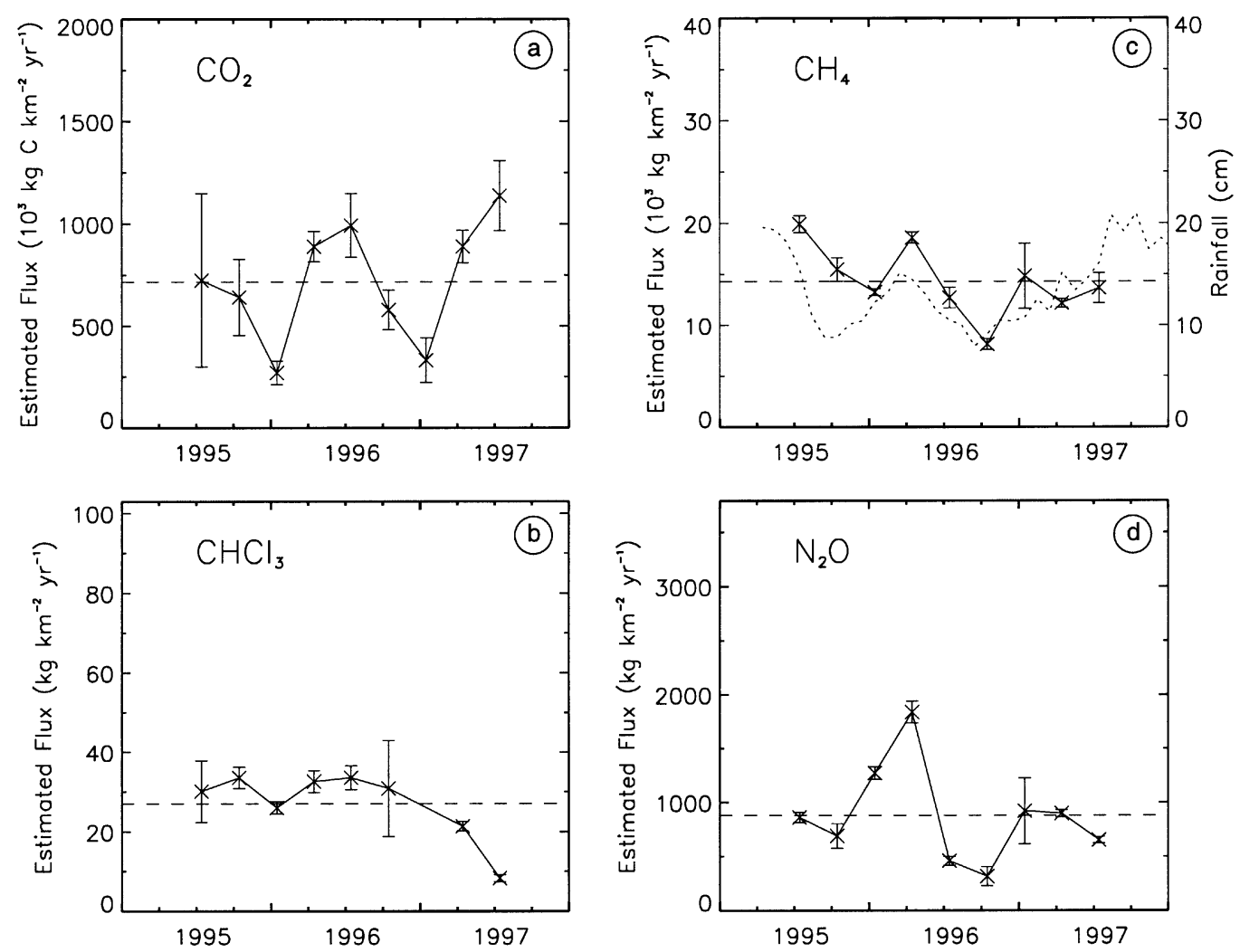

Fig. 6. (a) $\mathrm{CO}_{2}$, (b) $\mathrm{CH}_{4}$, (c) $\mathrm{CHCl}_{3}$ and (d) $\mathrm{N}_{2} \mathrm{O}$ averaged fluxes over the period 1995/97. Fluxes are averaged over 3 month periods (December to February, March to May, June to August and September to November). The average flux calculated over the period 1995/97 is shown as a dashed line. For $\mathrm{CH}_{4}$, the dotted line shows rainfalls recorded at Shannon meteorological station over the period 1995/97.

Assuming that all the $\mathrm{CH}_{4}$ seasonal variation is related to $\mathrm{CH}_{4}$ emission from wetlands, would imply that wetlands contribute to $16 \%$ of the annual mean $\mathrm{CH}_{4}$ emissions. In contrast, CORINAIR inventories suggest that natural wetlands only represent $4 \%$ of the overall $\mathrm{CH}_{4}$ emissions in Ireland. Higher wetland emission inferred from Mace Head compare to CORINAIR could be due to the presence of large wetlands with $100 \mathrm{~km}$ of the station. Secondly, despite a short record, one also can notice a possible negative trend in the $\mathrm{CH}_{4}$ emission flux. We estimate this trend to be on the order of $30 \%$ over the period 1995/97. It is worth noting that Levin et al. (1999) have also observed a $20 \%$ decrease in the emission flux of $\mathrm{CH}_{4}$ in southwest Germany over the period 1995/97. We also noticed that $\mathrm{CH}_{4}$ emission fluxes are correlated with rainfalls recorded at Shannon meteorological station $\left(52^{\circ} 7^{\prime} \mathrm{N}, 8^{\circ} 91^{\prime} \mathrm{W}\right)$, maximum and minimum $\mathrm{CH}_{4}$ emission flux being estimated at the same time as maximum and minimum rainfalls, respectively.

Mattsson (1970) and Whittlestone et al. (1998) measured a seasonal increase in ${ }^{222} \mathrm{Rn}$ emission flux from spring to summer at sites in Finland and Tasmania, respectively. They argued that the low ${ }^{222} \mathrm{Rn}$ emission flux was caused by a rise in the water table to near ground level, inhibiting ${ }^{222} \mathrm{Rn}$ emission by clogging of the soil pores. Whittlestone et al. (1998) measured ${ }^{222} \mathrm{Rn}$ emission fluxes that were $50 \%$ larger during summertime than during wintertime. We estimated the water table variation over Ireland with season from the output of a vegetation atmosphere transfer model (Ducoudre et al., 1993). It shows that the water table changes by less than $20 \%$ between spring- 
time and summertime. According to eq. (3), the inferred $\mathrm{CH}_{4}$ flux is proportional to the assumed ${ }^{222} \mathrm{Rn}$ flux. During wintertime, the ${ }^{222} \mathrm{Rn}$ flux is lower than during summertime because of the influence of water in the soil. Normalizing the ${ }^{222} \mathrm{Rn}$ emission flux to the water table would lead to emission fluxes $20 \%$ larger during summertime, and thus would increase the seasonal variation of the $\mathrm{CH}_{4}$ inferred flux.

\subsection{Nitrous oxide flux estimates}

The $\mathrm{N}_{2} \mathrm{O}-{ }^{222} \mathrm{Rn}$ slope over the period 1995/97 is on the order of $1.2 \mathrm{ppb} / \mathrm{Bq} \mathrm{m}^{-3}$ (Table 1 ). As for $\mathrm{CH}_{4}$, the value of this slope is 3 times larger than the one established by Biraud et al. (2000) for Western Europe $\left(0.5 \mathrm{ppb} / \mathrm{Bq} \mathrm{m}^{-3}\right)$. The inferred $\mathrm{N}_{2} \mathrm{O}$ average flux is of $680 \mathrm{~kg} \mathrm{~N}_{2} \mathrm{O}$ $\mathrm{km}^{-2} \mathrm{yr}^{-1}$.

Inventoried anthropogenic $\mathrm{N}_{2} \mathrm{O}$ emission in Ireland by CORINAIR is 610 and $430 \mathrm{~kg} \mathrm{~N}_{2} \mathrm{O}$ $\mathrm{km}^{-2} \mathrm{yr}^{-1}$ for the years 1990 and 1994, respectively. The major difference between the 1990 and 1994 estimates is due to $\mathrm{N}_{2} \mathrm{O}$ emission fluxes from agricultural soils, which are estimated to be on the order of 570 and $340 \mathrm{~kg} \mathrm{~N}_{2} \mathrm{O} \mathrm{km} \mathrm{km}^{-2} \mathrm{yr}^{-1}$ for the years 1990 and 1994, respectively. Unfortunately, in the first national communication, no details were given on the estimation method. Part of this discrepancy between the two estimates is caused by the use of the revised 1996 IPCC guidelines for national greenhouse gas inventories in 1994, which include a new methodology for $\mathrm{N}_{2} \mathrm{O}$ emissions from agriculture. This new methodology does not include emissions associated with animal waste management systems other than grazing animal, nor indirect emissions such as nitrogen leaching. This suggests that CORINAIR94 inventoried emissions from agriculture are underestimated. In Ireland, according to the CORINAIR94 inventory, the major anthropogenic $\mathrm{N}_{2} \mathrm{O}$ source is contributed by the use of fertilizers in agriculture $(79 \%$ of the total), with production processes by inorganic chemical industries $(10 \%)$, with combustion in energy and transformation industries $(6 \%)$, and other minor sources $(5 \%)$ being the remaining contributors. The EDGAR 2.0 database estimates a $\mathrm{N}_{2} \mathrm{O}$ emission flux over Ireland of $200 \mathrm{~kg} \mathrm{~N}_{2} \mathrm{O}$ $\mathrm{km}^{-2} \mathrm{yr}^{-1}$ for year 1990. The difference between EDGAR 2.0 database and CORINAIR94 inventories mainly results from the fact that emissions factors used in CORINAIR inventories are based on areas, while for the EDGAR inventory, emissions estimates are related to the amount of fertilizer used. Making the reasonable assumption that most fertilized croplands emit $\mathrm{N}_{2} \mathrm{O}$ to the atmosphere, the $\mathrm{N}_{2} \mathrm{O}$ source must be widespread over large regions of Ireland, and therefore reasonably well collocated with ${ }^{222} \mathrm{Rn}$ emissions. We believe that the ${ }^{222} \mathrm{Rn}$-based approach should give a result comparable to $\mathrm{N}_{2} \mathrm{O}$ emissions estimated by inventories, and thus points out uncertainties related to inventoried $\mathrm{N}_{2} \mathrm{O}$ emissions over Ireland.

There is evidence to show that forest soils and grasslands emit $\mathrm{N}_{2} \mathrm{O}$ (Mosier et al., 1981). Natural $\mathrm{N}_{2} \mathrm{O}$ sources by soils are not included in the CORINAIR and EDGAR 2.0 inventories. Krieleman and Bouwman (1994) estimated that at the global scale, emissions from natural grasslands represent $5-20 \%$ of the total identified sources of $\mathrm{N}_{2} \mathrm{O}$. The natural $\mathrm{N}_{2} \mathrm{O}$ contribution for Ireland can be estimated from measurements of forested areas and natural grasslands (Skiba et al., 1996). We estimate that natural $\mathrm{N}_{2} \mathrm{O}$ emissions in Ireland are of the order of $50 \mathrm{~kg} \mathrm{~N} \mathrm{~N}_{2} \mathrm{O}$ $\mathrm{km}^{-2} \mathrm{yr}^{-1}$. The sum of the inventoried anthropogenic and natural $\mathrm{N}_{2} \mathrm{O}$ fluxes over Ireland is estimated to be $660 \mathrm{~kg} \mathrm{~N}_{2} \mathrm{O} \mathrm{km} \mathrm{km}^{-2} \mathrm{yr}^{-1}$ and $480 \mathrm{~kg}$ $\mathrm{N}_{2} \mathrm{O} \mathrm{km} \mathrm{km}^{-2} \mathrm{yr}^{-1}$ for the years 1990 and 1994, respectively. Our estimate compares well with the CORINAIR90 inventory.

In Fig. 6d, we observe that the $\mathrm{N}_{2} \mathrm{O}$ inferred emissions are seasonal, with higher emissions during springtime and lower during fall time. This could reflect the timing of the application of nitrogen fertilizers in agriculture with emission being maximum few days after fertilization (Clayton et al., 1994).

\subsection{Chloroform flux estimates}

The $\mathrm{CHCl}_{3}{ }^{-222} \mathrm{Rn}$ slope over the period $1995 / 97$ is of $13 \mathrm{ppt} / \mathrm{Bq} \mathrm{m}^{-3}$ (Table 1). The corresponding $\mathrm{CHCl}_{3}$ flux is of $20 \mathrm{~kg} \mathrm{CHCl}_{3} \mathrm{~km}^{-2} \mathrm{yr}^{-1}$.

Khalil and Rasmussen (1999), using time series of $\mathrm{CHCl}_{3}$ concentrations from 1985 to 1996 at the surface of the polar, middle and tropical latitudes of both hemispheres, determined the emission rate of $\mathrm{CHCl}_{3}$ from different latitudinal belts. They estimated a Northern hemisphere mid-latitude $\left(30^{\circ} \mathrm{N}-60^{\circ} \mathrm{N}\right)$ emission rate of $280 \pm 4010^{9} \mathrm{~g}$ $\mathrm{CHCl}_{3} \mathrm{yr}^{-1}$. We calculated the surface of this 
latitudinal belt to be on the order of $108 \mathrm{~km}^{2}$, leading to a mean flux of the order of $2.8 \pm 0.4 \mathrm{~kg}$ $\mathrm{CHCl}_{3} \mathrm{~km}^{-2} \mathrm{yr}^{-1}$ over the latitudinal belt $30^{\circ} \mathrm{N}-60^{\circ} \mathrm{N}$. Khalil et al. (1999) have shown that $\mathrm{CHCl}_{3}$ emissions from the ocean are three times lower than those from land at northern midlatitude. Knowing the continental-ocean surface ratio over the latitudinal belt $30^{\circ} \mathrm{N}-60^{\circ} \mathrm{N}$, we deduced the $\mathrm{CHCl}_{3}$ emission flux over the continents is $4.2 \pm 0.6 \mathrm{~kg} \mathrm{CHCl}_{3} \mathrm{~km}^{-2} \mathrm{yr}^{-1}$

There is no estimate of the $\mathrm{CHCl}_{3}$ emissions over Ireland. Dimmer et al. (2000) made direct flux measurements of $\mathrm{CHCl}_{3}$ over peat lands in the vicinity of the Mace Head station in September 1998 using static chambers. They observed an inhibition of $\mathrm{CHCl}_{3}$ emissions with solar radiation, the $\mathrm{CHCl}_{3}$ flux being higher during night-time than during daytime. Dimmer et al. (2000) also suggested that $\mathrm{CHCl}_{3}$ fluxes have a large spatial variability near Mace Head, with daytime emissions rates that ranged from $4.5 \mathrm{~kg} \mathrm{CHCl}_{3}$ $\mathrm{km}^{-2} \mathrm{yr}^{-1}$ in peat bogs to $146 \mathrm{~kg} \mathrm{CHCl}_{3}$ $\mathrm{km}^{-2} \mathrm{yr}^{-1}$ in conifer forests. Their elevated forest fluxes of $\mathrm{CHCl}_{3}$ are attributed to the filtering of the sea salt by the high surface area of the pine needles causing extra deposition to the forest floor, which is then recycled biologically as $\mathrm{CHCl}_{3}$. The relatively narrow range of standard deviation that we determined for the $\mathrm{CHCl}_{3}{ }^{222} \mathrm{Rn}$ slope $(<20 \%)$ is in contradiction with such a spatially heterogeneous $\mathrm{CHCl}_{3}$ source. Adding in our data selection events associated to a fetch lower than $50 \mathrm{~km}$ leads to larger standard deviation and $\mathrm{CHCl}_{3}$ flux estimate on the order of $50 \mathrm{~kg} \mathrm{CHCl} \mathrm{km}^{-2} \mathrm{yr}^{-1}$.

According to a land cover map of Ireland from CORINE, $56 \%$ of the total land surface is associated with pastures for sheep and cattle grazing, $17 \%$ is classified as peat bogs mainly located in Connemara and only $3.5 \%$ is classified as coniferous forest (Table 3). Assuming that Dimmer et al. (2000) determine $\mathrm{CHCl}_{3}$ emission fluxes over peat bogs, forested areas, and pastures, we estimate a mean $\mathrm{CHCl}_{3}$ emission flux over Ireland of $6 \mathrm{~kg}$ $\mathrm{CHCl}_{3} \mathrm{~km}^{-2} \mathrm{yr}^{-1}$. This estimate is 3 times lower than our $\mathrm{CHCl}_{3}$ inferred flux. However, it must be noted that flux estimates determined by Dimmer et al. were only over a very short time period and may not accurately account for the average flux.

As shown in the data selection, more than $80 \%$ of the selected local events occur during night- time (Figs. 1 and 3). Dimmer et al. (2000) have shown the night-time flux of $\mathrm{CHCl}_{3}$ from coniferous forest to be triple the daytime flux. Our inferred $\mathrm{CHCl}_{3}$ emission flux is thus an overestimate of the mean daytime $\mathrm{CHCl}_{3}$ emission flux over Ireland. Knowing the frequency distribution of selected events (Fig. 3), and the ratio of day to night $\mathrm{CHCl}_{3}$ fluxes from the study by Dimmer, we can compare the daytime $\mathrm{CHCl}_{3}$ flux measured by Dimmer et al. and the $\mathrm{CHCl}_{3}$ flux we inferred using the atmospheric approach. We estimate a $\mathrm{CHCl}_{3}$ daytime emission flux of the order of $10-15 \mathrm{~kg} \quad \mathrm{CHCl}_{3} \mathrm{~km}^{-2} \mathrm{yr}^{-1}$. To estimate the $\mathrm{CHCl}_{3}$ emission flux over Ireland from direct flux measurements, we arbitrarily assumed that $\mathrm{CHCl}_{3}$ emission fluxes from types of land cover other than peat bogs $(17 \%$ of the total land surface $)$ and coniferous forests $(3 \%$ of the total land surface) are close to zero. Conversely, to balance the daytime $\mathrm{CHCl}_{3}$ emission flux over Ireland we inferred from atmospheric measurements, a $\mathrm{CHCl}_{3}$ emission flux of the order of $15 \mathrm{~kg} \mathrm{CHCl}_{3}$ $\mathrm{km}^{-2} \mathrm{yr}^{-1}$ would be required on $80 \%$ of the surface of Ireland. The discrepancy between the two methods can be explained by the fact that Dimmer et al. (2000) measured $\mathrm{CHCl}_{3}$ emission fluxes for only two particular types of land cover. Anthropogenic emissions of $\mathrm{CHCl}_{3}$ have been distributed globally on a $1^{\circ} \times 1^{\circ}$ grid mesh by Aucott et al. (1999). It shows that industrial $\mathrm{CHCl}_{3}$ emissions are much smaller than natural $\mathrm{CHCl}_{3}$ emissions. We estimated the contribution of the anthropogenic source of $\mathrm{CHCl}_{3}$ over Ireland to be on the order of $60 \mathrm{~g} \mathrm{CHCl}_{3} \mathrm{~km}^{-2} \mathrm{yr}^{-1}$.

Our $\mathrm{CHCl}_{3}$ emission fluxes estimate is consistent with the interpretation of the same data by Ryall (personal communication, 2000), who obtained, using a Lagrangian atmospheric transport model (Ryall et al., 1998), $\mathrm{CHCl}_{3}$ fluxes of $24 \pm 7 \mathrm{~kg} \mathrm{CHCl}_{3} \mathrm{~km}^{-2} \mathrm{yr}^{-1}$.

\section{5. $\mathrm{CO}_{2}$ flux estimates}

The $\mathrm{CO}_{2}$ biospheric fluxes are expected to be seasonal, with vegetated areas acting as a net source to the atmosphere in winter and as a net sink during the growing season. Therefore we need to discuss the inferred winter and summer fluxes separately. Furthermore, as evidenced by in the data selection, most of the selected events occur during the night. Thus, the main biospheric contri- 
bution to the natural emissions is associated with terrestrial ecosystems respiration.

During wintertime, we calculated a $\mathrm{CO}_{2}{ }^{-222} \mathrm{Rn}$ average slope of $1.5 \mathrm{ppm} / \mathrm{Bq} \mathrm{m}^{-3}$ (Table 1 ). This slope estimate for Ireland can be compared to the value measured by Schmidt et al. (1996) for western Germany of $4.8 \pm 0.6 \mathrm{ppm} / \mathrm{Bq} \mathrm{m}^{-3}$. Our slope corresponds to a $\mathrm{CO}_{2}$ source during wintertime of $250 \times 10^{3} \mathrm{~kg} \mathrm{C} \mathrm{km}^{-2} \mathrm{yr}^{-1}$, whereas Schmidt et al. (1996) inferred wintertime $\mathrm{CO}_{2}$ emissions of $1100 \times 10^{3} \mathrm{~kg} \mathrm{C} \mathrm{km}^{-2} \mathrm{yr}^{-1}$. This discrepancy is likely due to the $\mathrm{CO}_{2}$ emission fluxes from fossil fuel being much larger in Germany than in Ireland. To compare our estimate with inventories we need to account for both natural and fossil fuel sources. For the fossil fuel source we will use the estimate made by CORINAIR94 of $130 \times 10^{3} \mathrm{~kg} \mathrm{C}$ $\mathrm{km}^{-2} \mathrm{yr}^{-1}$ for 1994 , close to the one made by Andres et al. (1996) for Ireland $\left(130 \times 10^{3} \mathrm{~kg} \mathrm{C}\right.$ $\mathrm{km}^{-2} \mathrm{yr}^{-1}$ in 1995 and $150 \times 10^{3} \mathrm{~kg} \mathrm{C} \mathrm{km}^{-2} \mathrm{yr}^{-1}$ in 1996). The coldest months are January and February, with mean daily air temperatures of between 4 and $7^{\circ} \mathrm{C}$, while June and August are the warmest months, with mean temperatures of between 14 and $16^{\circ} \mathrm{C}$. We assume that fossil $\mathrm{CO}_{2}$ emissions show a seasonal pattern (Rotty, 1987). According to the CORINAIR 1994 inventory, fossil $\mathrm{CO}_{2}$ emissions are attributed to road transport $(17 \%)$, industrial processes $(55 \%)$, and heating $(28 \%)$. Assuming that fossil fuel $\mathrm{CO}_{2}$ emissions from heating are maximum during wintertime and minimum during summertime would lead to total fossil $\mathrm{CO}_{2}$ emissions of the order of $240 \times 10^{3}$ and $95 \times 10^{3} \mathrm{~kg} \mathrm{C} \mathrm{km}^{-2} \mathrm{yr}^{-1}$ during wintertime and summertime, respectively. As for the $\mathrm{CO}_{2}$ flux from heterotrophic respiration we will use the value predicted by one global biogeochemical model (Friedlingstein et al., 1995). We obtain a wintertime heterotrophic respiration $\mathrm{CO}_{2}$ flux of the order of $300 \times 10^{3} \mathrm{~kg} \mathrm{C} \mathrm{km}^{-2} \mathrm{yr}^{-1}$ over Ireland. The sum of the anthropogenic and net natural flux during wintertime is thus of the order $540 \times 10^{3} \mathrm{~kg} \mathrm{C} \mathrm{km}^{-2} \mathrm{yr}^{-1}$ over Ireland.

During summertime, we calculated a $\mathrm{CO}_{2}-$ ${ }^{222} \mathrm{Rn}$ average slope on the order of $4.6 \mathrm{ppm} / \mathrm{Bq} \mathrm{m}^{-3}$ (Table 1). Our slope corresponds to a $\mathrm{CO}_{2}$ flux during summertime on the order of $760 \times 10^{3} \mathrm{~kg} \mathrm{C} \mathrm{km}^{-2} \mathrm{yr}^{-1}$. To compare our estimate to inventories we also need to account for the sum of natural and anthropogenic fluxes estimates. We assume that fossil $\mathrm{CO}_{2}$ emissions are
ADDINnot seasonal. Furthermore, as shown in the data selection, most of the selected events occur during the night. Thus, the main biospheric contribution to the natural emissions is associated with terrestrial ecosystems respiration. This explains why we estimate larger $\mathrm{CO}_{2}$ emission fluxes during summertime. We estimate summertime $\mathrm{CO}_{2}$ source from terrestrial ecosystems respiration using the output of the same global biogeochemical model as previously, and we obtain summertime terrestrial heterotrophic respiration $\mathrm{CO}_{2}$ flux of the order of $700 \times 10^{3} \mathrm{~kg} \mathrm{C}$ $\mathrm{km}^{-2} \mathrm{yr}^{-1}$ over Ireland. The sum of the anthropogenic and net natural flux during summertime is estimated from this calculation to be 795 $\times 10^{3} \mathrm{~kg} \mathrm{C} \mathrm{km}^{-2} \mathrm{yr}^{-1}$ over Ireland.

Our estimation of the $\mathrm{CO}_{2}$ emission flux during summer and winter nights are close to that estimated from inventories and one particular biogeochemical model of heterotrophic respiration. A large uncertainty is, however, associated with the biochemical model prediction. A study by Heimann et al. (1998) has shown that heterotrophic respiration estimations using global biogeochemical models vary by a factor of two.

\section{Sensitivity study}

We examined the sensitivity of our results to all parameters that could influence the data selection: the ${ }^{222} \mathrm{Rn}$ and ${ }^{212} \mathrm{~Pb}$ thresholds, the minimal duration of the selected events, and the fetch (distance of influence).

As a sensitivity test, we selected events by varying ${ }^{222} \mathrm{Rn}$ thresholds from 50 to $1500 \mathrm{mBq}$ $\mathrm{m}^{-3}$. The inferred fluxes are little affected by such a change $(<25 \%)$ in comparison to the ${ }^{222} \mathrm{Rn}$ threshold value chosen in this study $\left(300 \mathrm{mBq} \mathrm{m}^{-3}\right)$. We also tested the influence of ${ }^{212} \mathrm{~Pb}$ threshold, by varying its values between 5 and $30 \mathrm{mBq} \mathrm{m}^{-3}$. The inferred fluxes decreased by $25 \%$ when the ${ }^{212} \mathrm{~Pb}$ threshold increased. For ${ }^{212} \mathrm{~Pb}$ thresholds greater than $30 \mathrm{mBq} \mathrm{m}^{-3}$ the number of retained events was too small $(<30$ events) to infer fluxes. We selected events by varying minimal duration in time from 2 to $12 \mathrm{~h}$. The inferred fluxes were decreased by $20 \%$.

The fetch is also a critical parameter in the data selection. We decided to select events according to their ${ }^{222} \mathrm{Rn}$ and ${ }^{212} \mathrm{~Pb}$ concentrations. In this 

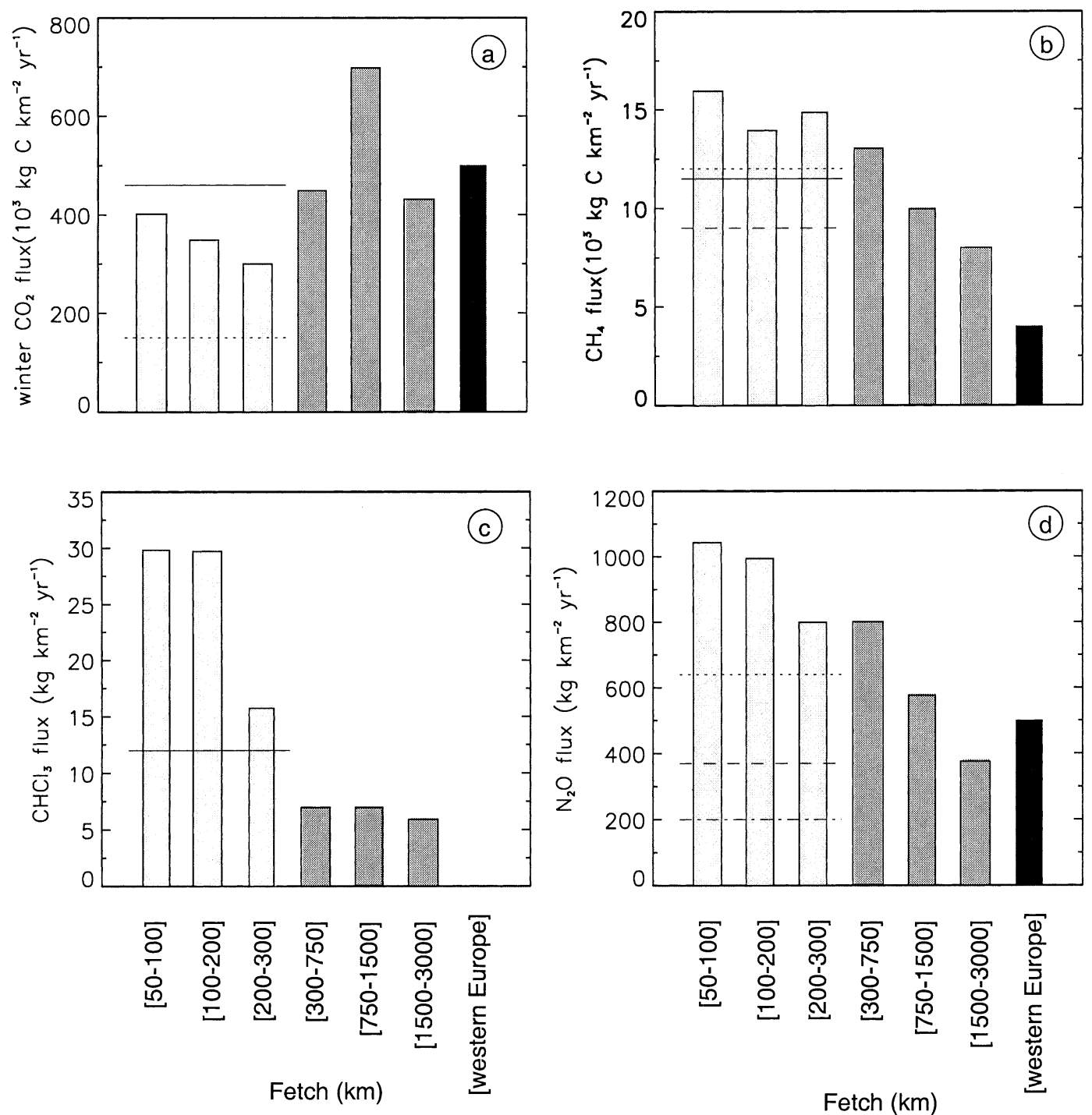

Fig. 7. Inferred fluxes as a function of the distance of influence (fetch). Fluxes are given in $10^{3} \mathrm{~kg} \mathrm{CH}_{4} \mathrm{~km}^{-2} \mathrm{yr}^{-1}$, $\mathrm{kg} \mathrm{N}_{2} \mathrm{O} \mathrm{km} \mathrm{kr}^{-1}, \mathrm{~kg} \mathrm{CHCl}_{3} \mathrm{~km}^{-2} \mathrm{yr}^{-1}, 10^{3} \mathrm{~kg} \mathrm{C} \mathrm{km}^{-2} \mathrm{yr}^{-1}$, for $\mathrm{CH}_{4}, \mathrm{~N}_{2} \mathrm{O}, \mathrm{CHCl}_{3}$, and wintertime $\mathrm{CO}_{2}$, respectively. For $\mathrm{CH}_{4}$ and $\mathrm{N}_{2} \mathrm{O}$, solid lines, dashed lines, and dotted lines, correspond to the inventoried flux over Ireland according to CORINAIR90, CORINAIR94 and EDGAR 2.0, respectively. For wintertime $\mathrm{CO}_{2}$, dotted line and solid line correspond to fossil sources only and both fossil and natural sources inventoried over Ireland. As for $\mathrm{CHCl}_{3}$, solid line corresponds to the mean $\mathrm{CHCl}_{3}$ emission flux estimated by Dimmer et al. (2000) over peatland of Connemara.

selected data set, all events originating from Western Europe are first selected. By Europe, we mean that we selected events dominated by Western Europe influences, as well as events influenced by Irish sources. This data set is then sorted into events of increasing fetch. In Fig. 7 we present the $\mathrm{CO}_{2}, \mathrm{CH}_{4} \mathrm{~N}_{2} \mathrm{O}$ and $\mathrm{CHCl}_{3}$ inferred fluxes as a function of the fetch. We notice that for larger fetches, greater than $1000 \mathrm{~km}$, the inferred fluxes converge toward the formerly inferred western

Tellus 54B (2002), 1 
European flux (Biraud et al., 2000). Conversely, for a fetch lower than $300 \mathrm{~km}$, inferred fluxes tends to become equal the Irish inferred flux. Almost all species have the same behavior, except for $\mathrm{CO}_{2}$, having emissions fluxes over Ireland greater than the one estimated over Western Europe.

\section{Summary and conclusions}

The Global Warming Potential (GPW) is useful to assess the relative roles of different greenhouse gases. $\mathrm{CO}_{2}$ is used as the reference. The GWPs of $\mathrm{CH}_{4}, \mathrm{~N}_{2} \mathrm{O}$, at the time horizon of $100 \mathrm{yr}$, as used in the Kyoto protocol, is on the order of $24.5 \pm 7.5$, and 320, respectively (IPCC, 1994). Using GWPs to express our estimated fluxes of $\mathrm{CH}_{4}$ and $\mathrm{N}_{2} \mathrm{O}$ over Ireland in equivalent $\mathrm{CO}_{2}$ fluxes will lead to fluxes of 1000, 330, and $240103 \mathrm{~kg} \mathrm{CO}_{2} \mathrm{~km}^{-2} \mathrm{yr}^{-1}$ for $\mathrm{CO}_{2}, \mathrm{CH}_{4}$ and $\mathrm{N}_{2} \mathrm{O}$, respectively. Emissions of $\mathrm{N}_{2} \mathrm{O}$ and $\mathrm{CH}_{4}$ therefore sum up to $50 \%$ of the emission of Ireland under the Kyoto accounting rule.

We estimated the fluxes of $\mathrm{CO}_{2}, \mathrm{CH}_{4}, \mathrm{~N}_{2} \mathrm{O}$ and $\mathrm{CHCl}_{3}$ over Ireland using the continuous atmospheric record of these species at the Mace Head atmospheric research station based on ${ }^{222} \mathrm{Rn}$ as a reference compound. The reference period that we analyzed is 1995-97. The uncertainties in the fluxes derived from ${ }^{222} \mathrm{Rn}$ is estimated to be of the order of $30 \%$. However, this approach is independent from inventories and does not use an explicit parameterization of the atmospheric transport. We determined both wintertime and summer nighttime fluxes for $\mathrm{CO}_{2}$, and the mean annual fluxes for all other species. We obtained mean flux densities on the order of $250 \times 10^{3} \mathrm{~kg} \mathrm{C} \mathrm{km}^{-2} \mathrm{yr}^{-1}$ and $760 \times 10^{3} \mathrm{~kg} \mathrm{C} \mathrm{km}^{-2} \mathrm{yr}^{-1}$ for $\mathrm{CO}_{2}$ during wintertime and summertime, respectively. We estimated emission fluxes of $(12-15) \times 10^{3} \mathrm{~kg}$ $\mathrm{CH}_{4} \mathrm{~km}^{-2} \mathrm{yr}^{-1}, 680-830 \mathrm{~kg} \mathrm{~N}_{2} \mathrm{O} \mathrm{km}{ }^{-2} \mathrm{yr}^{-1}$, and 20-30 kg km-2 $\mathrm{yr}^{-1}$ for $\mathrm{CH}_{4}, \quad \mathrm{~N}_{2} \mathrm{O}$ and $\mathrm{CHCl}_{3}$, respectively. Our $\mathrm{CH}_{4}$ inferred flux compares favourably with the CORINAIR90 and CORNAIR94 inventories for Ireland. The $\mathrm{N}_{2} \mathrm{O}$ emission flux we inferred is close to the one inventoried by CORINAIR90, but twice the value inventoried by CORINAIR94 and EDGAR 2.0. This discrepancy may have been caused by the use of the revised 1996 IPCC guidelines for national greenhouse gas inventories in 1994, which include a new methodology for $\mathrm{N}_{2} \mathrm{O}$ emissions from agriculture. We obtained a first estimation of $\mathrm{CHCl}_{3}$ emission fluxes over Ireland, demonstrating that emissions from natural sources were four times larger than those measured over peatlands close to the Mace Head station. Our estimates of the $\mathrm{CO}_{2}$ emission fluxes during summer night-time and wintertime are close to those estimated from inventories and the one biogeochemical model of heterotrophic respiration.

Inferred flux from this atmospheric method strongly depends on the estimated emission flux of ${ }^{222} \mathrm{Rn}$ over Ireland. Uncertainties on the inferred fluxes could be reduced if seasonal as well as spatial variations of ${ }^{222} \mathrm{Rn}$ fluxes were taken into account.

\section{Acknowledgements}

This work has been funded by the Irish Environmental Protection Agency, through the LS-5.3.1(b) grant. The Mace Head measurements analyzed in this work are carried on in Ireland by the National University of Ireland, Galway, in the UK by International Science Consultants (ISC), and in France by the Laboratoire des Sciences du Climat et de l'Environnement, Commissariat à l'Energie Atomique (CEA) and the Commission Spécialisée Océan Atmosphepe (CSOA) of the Centre National de la Recherche Scientifique (CNRS). We specifically acknowledge the cooperation of all members of the AGAGE team (R. Prinn, R. Weiss, P. Fraser, P. Steele, D. Cunnold and F. Alyea) in collecting and calibrating the Mace Head measurements. The operation of the Mace Head station was supported as part of the UK Department of the Environment, Transport, and the Regions Global Atmospheres Division, under contracts PECD 7/10/154 and EPG $1 / 1 / 37$. We also acknowledge the CORINE Land Cover database. LSCE contribution number 0651. 


\section{REFERENCES}

Andres, R. J., Marland, G., Fung, I. and Matthews, E. 1996. A 1 degrees $\times 1$ degrees distribution of carbon dioxide emissions from fossil fuel consumption and cement manufacture, 1950-1990. Global Biogeochem. Cycles 10, 419-429.

Aucott, M. L., McCulloch, A., Graedel, T. E., Kleiman, G., Midgley, P. and Yi-Fan, Li, 1999. Anthropogenic emissions of trichloromethane (chloroform, $\mathrm{CHCl}_{3}$ ) and chlorodifluoromethane (HCFC-22) reactive chlorine emissions inventory. J. Geophys. Res. 104, 8405-8415.

Biraud, S., Ciais, P., Ramonet, M., Simmonds, P. Kazan, V., Monfray, P., O'Doherty, S., Spain, T. G. and Jennings, S. G. 2000. European greenhouse gas emissions estimated from continuous atmospheric measurements and radon 222 at Mace Head, Ireland J. Geophys. Res. 105, 1351-1366.

Bousquet, P., Gaudry, A., Ciais, P., Kazan, V., Monfray, P., Simmonds, P. G., Jennings, S. G. and O'Connor, T. C. 1996. Atmospheric $\mathrm{CO}_{2}$ concentration variations recorded at Mace Head, Ireland, from 1992 to 1994. Phys. Chem. Earth 21, 477-481.

Bousquet, P., Ciais, P., Peylin, P., Ramonet, M. and Monfray, P. 1999. Inverse modeling of annual atmospheric $\mathrm{CO}_{2}$ sources and sinks, 1 , Method and control inversion. J. Geophys. Res. 104, 26,161-26,178.

Clayton, H., Arah J. R. M. and Smith, K. A. 1994 Measurements of nitrous oxide emissions from fertilized grassland using closed chambers. J. Geophys. Res 99, 16,599-16,607.

CORINE land cover, http://etc.satellus.se/the_data/ overview.htm

Department of the Environment, Ireland April 1999. Report of the consultancy study on the limitation and reduction of $\mathrm{CO}_{2}$ and other greenhouse gas emissions in Ireland. Press release.

Dimmer, C. H., Simmonds, P. G., Nickless G. N. and Bassford, M. R. 2000. Biogenic fluxes of halomethanes from Irish Peatland Ecosystems. Atmos. Environ. 35 321-330.

Dörr, H. and Münnich, K. O. 1990. ${ }^{222}$ Rn flux and soil air concentration profiles in West Germany. Soil ${ }^{222} \mathrm{Rn}$ as tracer for gas transport in the unsaturated soil zone Tellus 39B, 114-121.

Ducoudre, N. I., Laval, K. and Perrier, A. 1993. SECH IBA, a new set of parameterizations of the hydrologic exchanges at the land-atmosphere interface within the LMD atmospheric general circulation model J. Climate 6, 248-273.

Eckhardt, K. 1990. Messung des Radonflusses und seiner Abhängigkeit von der Bodenbeschaffenheit, Universität Heidelberg, Diplomarbeit, Heidelberg.

ECMWF, 1994. The description of the ECMWF/WCRP Level III-A global atmospheric data archive. Internal report, Shinfield Park, Reading/Berks, UK.

Frank, W. and Frank, H. 1990. Concentrations of air- borne $\mathrm{C} 1$ and $\mathrm{C} 2$ halocarbons in forest areas in west Germany: results of three campaigns in 1986, 1987 and 1988. Atmos. Environ. 24A, 1735-1739.

Friedlingstein, P., Fung, I., Holland, E., John, J., Brasseur, G., Erickson, D. and Schimel, D. 1995. On the contribution of $\mathrm{CO}_{2}$ fertilization to the missing biospheric sink. Global Biogeochem. Cycles 9, 541-556.

Gaudry, A., Ciais, P., Kazan, V. and Monfray, P. 1995. Report on the 8th WMO meeting of experts on carbon dioxide concentration and isotopic measurement techniques. WMO/GAW No. 121, Boulder, CO.

Hauglustaine, D. A., Braseur, G. P., Walters, S., Rasch, P. J., Muller, J. F., Emmons, L. K. and Carroll, M. A. 1998. MOZART, a global chemical transport model for ozone and related chemical tracers. J. Geophys. Res. 103, 28,291-28,335.

Heimann, M. et al. 1998. Evaluation of terrestrial carbon cycle models through simulations of the seasonal cycle of atmospheric $\mathrm{CO}_{2}$ : first results of a model intercomparison study. Global Biogeochem. Cycles $\mathbf{1 2}$ $1-24$.

Hoekstra, E. J., DeLeer, E. W. B. and Brinkman, U. A. Th. 1998. Natural formation of chloroform and brominated trihalomethanes in soil. Environ. Sci. Technol. 32, 3724-3729.

IPCC, 1994. Climate change 1994. Radiative forcing of climate change. An evaluation of the IPCC IS92 emissions scenarios, Cambridge University Press, Cambridge, $337 \mathrm{pp}$.

Isidorov, V. A., Zenkhevich, I. G. and Ioffe, B. V. 1990 Volatile organic compounds in solfatiric gases. J. Atmos. Chem. 10, 329-340.

Keene, W. C., Khalil, M. A. K., Erickson III, D. J., McCulloch, A., Graedel, T. E., Lobert, J. M., Aucott, M. L., Gong, S. L., Harper, D. B., Kleiman, G., Midgley, P., Moore, R. M., Seuzaret, C., Sturges, W. T., Benkovitz, C. M., Koropalov, V., Barrie L. A. and Fan Li, Y. 1999. Composite global emissions of reactive chlorine from anthropogenic and natural sources: reactive chlorine emissions inventory. J. Geophys. Res. 104, 8429-8440.

Khalil, M. A. K. and Rasmussen, R. A. 1999. Atmospheric chloroform. Atmos. Environ. 33, 1151-1158.

Khalil, M. A. K., Moore, R. M. Harper, D. B., Lobert, J. M. Erickson, D. J., Koropalov, V., Sturges W. T. and Keene, W. C. 1999. Natural emissions of chlorinecontaining gases: reactive chlorine emissions inventory. J. Geophys. Res. 104, 8333-8346.

Krieleman, G. and Bouwman, A. 1994. Computing land use emissions of greenhouse gases. J. Water, Air Soil Pollution 76, 231-258.

Kuhlmann, A. J., Worthy, D. E. J., Trivett N. B. A. and Levin, I. 1998. Methane emissions from wetland region within the Hudson bay lowland: an atmospheric approach. J. Geophys. Res. 103, 16,009-16,016.

Lambert, G., Polian, G., Sanak, J., Ardouin, B., Buis-

Tellus 54B (2002), 1 
son, A., Jegou, A. and Le Roulley, J. C. 1982. Cycle du radon et de ses descendants: application à l'étude des échanges troposphère-stratosphère. Ann. Geophys. 38, 497-531.

Levin, I., Glatzel Mattheier, H., Marik, T., Cuntz, M., Schmidt, M. and Worthy, D. E. 1999. Verification of german methane inventories and their recent changes based on atmospheric observations. J. Geophys. Res 104, 3447-3456.

Mattson, R. 1970. Seasonal variation of short lived radon progeny, ${ }^{210} \mathrm{~Pb}$ and ${ }^{210} \mathrm{Po}$, in ground level air in Finland. J. Geophys. Res. 75, 1741-1744.

McInnes, G. 1995. CORINAIR 1990 summary tables. European Environment Agency, Kobenhavn, Denmark.

Molin, M. J. and Rowland, F. S. 1974. Stratospheric sink for chlorofluoromethanes: chlorine atom catalyzed destruction of ozone. Nature 249, 810-812.

Mosier, A., Stillwell, M., Parton, W. and Wood manse, R. 1981. Nitrous oxide emissions from native short grass prairie. J. Soil Sci. Soc. Am. 45, 617-619.

Nazaroff, W. 1992. Radon transport from soil to air. Rev. Geophys. 30, 137-160.

Olivier, J. G. J., Bouwman, A. F., Berdowski, J. J. M., Veldt, C., Bloos, J. P. J., Visschedijk, A. J. H., van der Maas, C. W. M. and Zandveld, P. Y. J. 1999. Sectorial emission inventories of greenhouse gases for 1990 on a per country basis as well as on $1^{\circ} \times 1^{\circ}$. Environ. Sci. Policy 2, 241-263.

Polian, G., Lambert, G., Ardouin, B. and Jegou, A. 1986. Long-range transport of continental radon in subantarctic and antarctic areas. Tellus 38B, 178-189.

Prather, M. 1988. European sources of halocarbons and nitrous oxide: update 1986. J. Atmos. Chem. 6, 375-406.

Ramonet, M., Le Roulley, J. C., Bousquet, P. and Monfray, P. 1996. Radon-222 measurements during the TropozII campaign and comparison with a global atmospheric transport model. J. Atmos. Chem. 23, 107-136.

Ramonet, M., Ciais, P., Biraud, S., Bourg, C., Chamaret, P., Kazan, V. and Monfray, P. 1998. Report on the 9th WMO meeting of experts on carbon dioxide concentration and related tracer measurement technique. WMO/GAW No. 132, Aspendale, Australia.

Rotty, R. M. 1987. Estimates of seasonal variation in fossil fuel $\mathrm{CO}_{2}$ emissions. Tellus 39B, 184-202.

Rudolph, J., Khedim, A., Koppmann, R. and Bonsang, B. 1995. Field study of the emission of methyl chloride and other halocarbons from biomass burning in western Africa. J. Atmos. Chem. 22, 67-80.

Ryall, D. B., Maryon, R. H., Derwent, R. G. and Sim- monds, P. G. 1998. Modeling long-range transport of CFCs to Mace Head, Ireland. Q. J. R. Meteorol. Soc. 124, 417-446.

Schery, S. D., Whittlestone S. and Hart, K. P. 1989. The flux of radon and thoron from Australian soils. J. Geophys. Res. 94, 8567-8576.

Schery, S. D. 1986. Studies of thoron and thoron progeny: implications for transport of airborne radioactivity from soil to indoor air, indoor radon. Air Pollut. Control Assoc. SP-54, 25-36.

Schmidt, M., Graul, R., Sartorius, H. and Levin, I. 1996. Carbon dioxide and methane in continental Europe: a climatology, and ${ }^{222}$ radon-based emission estimates. Tellus 48B, 457-473.

Schmidt, M., Glazel-Mattheier, H., Satorius, H., Worthy D. E. and Levin, I. 2001, Western European $\mathrm{N}_{2} \mathrm{O}$ emissions - a top-down approach based on atmospheric observations. J. Geophys. Res. in press.

Simmonds, P. G., Derwent, R. G., McCulloch, A., O'Doherty, S. and Gaudry, A. 1996. Long-term trends in concentrations of halocarbons and radiatively active trace gases in Atlantic and European air masses monitored at Mace Head, Ireland from 1987-1994. Atmos. Environ. 30, 4041-4063.

Simpson, D., Winiwarter, W., Borjesson, G., Cinderby, S., Ferreiro, A., Guenther, A., Hewitt, C N., James, R., Khalil, M. A., Owen, S., Pierce, T. E., Puxbaum, H., Shearer, M., Skiba, U., Steinbrecher, R., Tarrason, L. and Oquist, M. G. 1999. Inventorying emissions from nature in Europe. J. Geophys. Res. 104, 8113-8152.

Skiba, U., McTaggart, I. P., Smith K. A., Hargreaves K. J. and Fowler, D. 1996. Estimates of nitrous oxide emissions from soil in the UK. Energy Convers. Mgmt. 37, 1303-1308.

Thoning, K. W., Tans, P. P. and Komhyr, W. D. 1994, Atmospheric carbon dioxide at Mauna Loa observatory 2. Analysis of the NOAA GMCC data, 1974-1985. J. Geophys. Res. 94, 8549-8565.

Turekian, K. K., Nozaki, Y. and Benninger, L. K. 1997. Geochemistry of atmospheric radon and radon products. Annu. Rev. Earth Planet. Sci. 5, 227-255.

Wilkening, M. H. and Clements, W. E. 1975. Radon 222 from the ocean surface. J. Geophys. Res. 80, 3828-3830. Wilson, S. R., Dick, A. L., Fraser, P. J. and Whittlestone, S. 1997. Nitrous oxide flux estimates for south eastern Australia. J. Atmos. Chem. 26, 169-188.

Whittlestone, S., Schery, S. D. and Li, Y. 1996. Thoron and radon fluxes from the island of Hawaii. J. Geophys. Res. 101, 14787-14794.

Whittlestone, S., Zahorowski, W. and Schery, S. D. 1998. Radon flux variability with season and location in Tasmania. J. Radio. Nucl. Chem. 236, 213-217. 